NBER WORKING PAPER SERIES

\title{
THE DEMAND FOR VARIETY: A HOUSEHOLD PRODUCTION PERSPECTIVE
}

\author{
Reuben Gronau \\ Daniel S. Hamermesh \\ Working Paper 8509 \\ http://www.nber.org/papers/w8509
NATIONAL BUREAU OF ECONOMIC RESEARCH
1050 Massachusetts Avenue
Cambridge, MA 02138 \\ October 2001
}

We thank Rachel Friedberg, Chris Taber, Jim Walker, Yoram Weiss and participants in seminars at several universities, the Bureau of Labor Statistics and the NBER for helpful comments. We are indebted to the Australian Bureau of Statistics for providing their data, the Central Bureau of Statistics for the Israeli data, the Steinmetz Archive for the Dutch data, Lennart Flood for the Swedish data, the Inter-university Consortium for Political and Social Research for the U.S. data, and the Statistisches Bundesamt for the German data. Shane Carbonneau, Abe Dunn, Alex Gershkov and Elaine Zimmerman provided excellent research assistance. Research support was provided by the National Science Foundation under Grant SES-9904699 and by the Binational Science Foundation. The views expressed herein are those of the authors and not necessarily those of the National Bureau of Economic Research.

(C) 2001 by Reuben Gronau and Daniel S. Hamermesh. All rights reserved. Short sections of text, not to exceed two paragraphs, may be quoted without explicit permission provided that full credit, including $\mathbb{C}$ notice, is given to the source. 
The Demand for Variety: A Household Production Perspective

Reuben Gronau and Daniel S. Hamermesh

NBER Working Paper No. 8509

October 2001

JEL No. J22, D12

\begin{abstract}
Product diversity pervades every modern marketplace, and economists have devoted substantial attention to firms' decisions about the supply of variety. This study looks at the consumer's side by discussing the demand for variety. Using the framework of the home-production model, we trace differences in demand to differences in the opportunity costs of various activities. The cost differences are associated with investments in human capital; and the resulting differences in schooling attainment produce differences in time costs that in turn alter the kinds and variety of activities in which household members engage. Using time-budget surveys from Australia, Israel, the Netherlands, Sweden, the United States and West Germany from between 1985 and 1994, we find substantial differences among households in the extent of variety in the nonwork activities that they produce. More educated individuals generate more variety, engaging in both additional activities and the same ones as the less educated, with most of the effect of education on the variety of nonroutine activities. There is more variety on weekends; women engage in more different activities than men; young children add to variety in household consumption/production, especially among women; and income effects are clearly positive.
\end{abstract}

Reuben Gronau

Department of Economics

Hebrew University

Jerusalem, Israel

and NBER

msreuben@mscc.huji.ac.il
Daniel S. Hamermesh

Department of Economics

University of Texas

Austin, TX 78712-1173

and NBER

hamermes@eco.utexas.edu 
Variety is the mother of enjoyment. Benjamin Disraeli, Vivian Grey

\section{Introduction and Motivation}

Product diversity is a salient feature of every modern marketplace. It is therefore unsurprising that it has played an increasingly important role in economic theory. With the work of Cournot it became the cornerstone of the analysis of oligopolistic competition, market structure and market power. It has since expanded into the theory of international trade to become an important element in the explanation of trade patterns. The emphasis in the literature, however, has in general been on supply factors - on firms' behavior (Chamberlin, 1933) and the optimal diversity of supply, with consumer demand for variety taken as given.

Borrowing a page from Hotelling, it is assumed that the distribution of consumers' tastes in product space is given (uniform along a straight line in Dixit and Stiglitz 1977, circular in Salop, 1977). The implicit assumption is that this distribution reflects the diversity of preferences (i.e., different tastes) and is unaffected by economic factors, essentially ruling out the effect of the standard economic variables, prices and income, as important sources of variation in consumer demand. $^{1}$

This neglect is not surprising. To analyze product variety one has to define the nature of the product, a definition most economists tend to shy away from. Measurement creates additional problems. The measure of product variety depends crucially on the level of data aggregation: The greater the level of aggregation, the smaller the observed variety. The degree of detail in the data (consumption and production surveys) depends often on the cost of data collection. An observed increase in product variety over time can therefore at least partly reflect increased resources devoted to data collection. This forces the researcher to infer the factors affecting variety from differences in behavior among various socioeconomic groups in cross-section surveys.

\footnotetext{
${ }^{1}$ Perhaps the only exception is Jackson (1984) who analyzed the effect of income on variety. More important, in the now quite large literature on home production (summarized by Gronau, 1986 and 1997), none has analyzed the variety of activities.
} 
This is the path that we take here. The novelty lies not so much in the formal model but rather in the framework used to analyze the demand for variety and in the breadth of evidence that we offer. Instead of studying the demand for goods, we analyze the underlying demand for activities, where each activity is "produced" à la Becker (1965) using goods and time.

Incorporating the time constraint into the analysis produces two departures from previous research. Whereas the budget constraint on goods is a "soft" one that allows households with higher income to indulge their tastes for variety without having to forego the consumption of additional quantities of goods, the time constraint is rigid: Rich and poor, high-wage and lowwage, all face the same time constraint - twenty-four hours every day. Increased variety in time use must come at the expense of the time spent on each activity. The time constraint binds even more tightly where diversity of consumption activities is concerned, since consumption time and material resources are often negatively correlated (because of the time spent working).

The other fundamental difference relates to price. In a world of linear pricing diversity carries no cost. Nonlinear pricing schemes are relatively rare, and it is only natural that the few researchers who have studied the demand for product diversity have ignored the price effect. One cannot, however, ignore setup costs where time is involved. Switching among activities involves time, and the amount of time "wasted" in this endeavor (for example, transport time) is far from negligible. Setup costs must, therefore, be incorporated in the analysis of variety.

In our empirical analyses we use six bodies of data, time use studies from: Australia 1992, Israel 1991/92, the Netherlands 1990, Sweden 1993-94, the United States 1985, and West Germany 1991/92. The analysis of variety confronts the researcher with problems unfamiliar in other contexts. Most statistical surveys measure economic activity (e.g., production, consumption, trade) over relatively long time spans (a month, quarter or year). They focus primarily on the total amounts of the activities that are undertaken over these long periods, and only secondarily on their dispersion over shorter time intervals. Research using time budgets has to console itself with much shorter time spans. Difficulties in data collection (e.g., recall 
problems) limit the observation period of time-use surveys to one to seven days, and variety in the number of activities increases with the length of time the subject is observed. This makes the measure of variety very sensitive to the time span reported. Even a week may be too short to capture the full extent of variation in consumption activity.

When the period covered by the survey is less than a week (e.g., all but the Dutch surveys used here) the researcher is confronted by another problem — that of periodicity. Market work is a major determinant of the time available for consumption activities. The constraint on consumption time shifts between workdays and weekends, resulting in changes in the number and nature of activities over the week. Temporal variation in the demand for variety is thus an additional topic of this research.

The study opens with a theoretical discussion of the demand for variety in a homeproduction context. The analysis is followed by a description of the six data sets that we use, and then moves to a brief discussion of the amounts of time allocated among different types of activities. Most of the discussion of the empirical results deals with aspects of the demand for variety, including its determinants, impacts on durations of activities, roles of routine and nonroutine activities, and differences between variety on weekdays and weekends.

\section{A Model of Variety in Household Production}

Standard consumption theory pays little attention to the question of variety. The representative consumer maximizes the utility function

$$
\mathrm{U}=\mathrm{U}\left(\mathrm{X}_{1}, \ldots, \mathrm{X}_{\mathrm{n}}\right)
$$

subject to a budget constraint

(2) $\quad \sum_{i=1}^{n} p_{i} X_{i}=I$,

where $\mathrm{X}_{\mathrm{i}}, \mathrm{p}_{\mathrm{i}}$ and I denote the quantity of goods and their prices, and money income. The number of goods available is arbitrary. The optimization rule states that the optimum market basket consists of the goods satisfying the condition 


$$
\mathrm{u}_{\mathrm{i}} / \mathrm{p}_{\mathrm{i}}=\mathrm{u}_{\mathrm{j}} / \mathrm{p}_{\mathrm{j}}=\lambda \quad \mathrm{i}, \mathrm{j}=1, \ldots, \mathrm{m},
$$

where $u_{i}=\partial U / \partial X_{i}$ is the marginal utility of good $i, \lambda$ (the Lagrangian multiplier) is the marginal utility of resources, and the goods are arbitrarily indexed to group them into the first $\mathrm{m}$ goods, which are consumed, and the n-m remaining goods, which are not. These latter satisfy the condition

$$
\overline{\mathrm{p}}_{\mathrm{i}}<\mathrm{p}_{\mathrm{i}}, \quad \mathrm{i}=\mathrm{m}+1, \ldots, \mathrm{n},
$$

where $\overline{\mathrm{p}}_{\mathrm{i}}$ is the reservation price, i.e., the maximum price the household is ready to pay for this $\operatorname{good} \bar{p}_{i}=u_{i}(0) / \lambda$

In this model product diversity can be explained either in terms of the dispersion of preferences (forsaking the assumption of a representative consumer) or by differences in incomes. Changes in income are associated with changes in marginal utility $\lambda$, so that diminishing marginal utility results in the expansion of the spectrum of goods consumed (m) as income increases. When the consumer confronts a nonlinear price system that includes setup costs (e.g., the access costs of maintaining a telephone or transportation costs to the location where the good is to be consumed), the household consumes the good only if the consumer surplus it derives exceeds the setup costs $c_{i}$, i.e., if:

$$
(1 / \lambda) \int_{p_{i}}^{\bar{p}_{i}} u_{i} d X_{i}(p) \geq c_{i}
$$

$\mathrm{p}_{\mathrm{i}}$

The theory of household production creates the scope for a much richer explanation. In this scheme (Becker, 1965) the subject of utility is not the good but the activity (Z), which in turn is produced by combining goods and time (T) according to

$$
\mathrm{Z}_{\mathrm{i}}=\mathrm{f}_{\mathrm{i}}\left(\mathrm{X}_{\mathrm{i}}, \mathrm{T}_{\mathrm{i}}\right)
$$

Maximization of the utility function $\mathrm{U}=\mathrm{U}\left(\mathrm{Z}_{1}, \ldots, \mathrm{Z}_{\mathrm{n}}\right)$ is subject to two constraints: the budget constraint (3), and the time constraint 


$$
\sum_{i=1}^{\mathrm{n}} \mathrm{T}_{\mathrm{i}}=\overline{\mathrm{T}}
$$

where $\overline{\mathrm{T}}$ denotes consumption time, and income I consists of wages and nonlabor sources of income. $\mathrm{I}=\mathrm{wL}+\mathrm{V}$, where $\mathrm{w}$ denotes the wage rate, $\mathrm{L}$ labor time inputs, and $\mathrm{V}$ nonlabor income. When the household is free to choose its labor time inputs (L), income (and the budget constraint) become an endogenous part of the model, and the household faces one ultimate constraint - the total time constraint $\left(\mathrm{T}_{0}\right)$ :

$$
\overline{\mathrm{T}}+\mathrm{L}=\mathrm{T}_{0}
$$

Optimization leads to the choice of producing/consuming those $\mathrm{m}$ activities that satisfy the condition

$$
\mathrm{u}_{\mathrm{i}} / \pi_{\mathrm{i}}=\lambda, \mathrm{i}=1, \ldots, \mathrm{m},
$$

where $u_{i}=\partial U / \partial Z_{i}$ is the marginal utility of activity $i, \lambda$ is the marginal utility of "effective time" $\left[\mathrm{T}_{0}+(\mathrm{V} / \mathrm{w})\right]$, and $\pi_{\mathrm{i}}$ denotes the marginal time cost of producing activity $i$. The marginal cost of the activity consists of two parts: The market time required to secure purchased inputs, and the home time required to produce the activity. The full price is then

$$
\pi_{\mathrm{i}}=\left(\mathrm{p}_{\mathrm{i}} / \mathrm{w}\right) \mathrm{x}_{\mathrm{i}}+\mathrm{t}_{\mathrm{i}}
$$

where $\mathrm{x}_{\mathrm{i}}=\partial \mathrm{X}_{\mathrm{i}} / \partial \mathrm{Z}_{\mathrm{i}}$ and $\mathrm{t}_{\mathrm{i}}=\partial \mathrm{T}_{\mathrm{i}} / \partial \mathrm{Z}_{\mathrm{i}}$ are the marginal goods and time inputs. The diversity of activities depends on the number of activities satisfying the condition

$$
\bar{\pi}_{\mathrm{i}}>\pi_{\mathrm{i}}, \mathrm{i}=1, \ldots, \mathrm{m}
$$

where $\bar{\pi}_{i}$ is the reservation price $u_{i}(0) / \lambda$.

In this model the diversity of activities undertaken arises not merely from the dispersion of preferences and incomes, but also from the dispersion of prices. Whereas the standard model assumes that all households face the same set of product prices $p_{i}$, this assumption does not hold 
for the set of activity prices $\pi_{\mathrm{i}}$. Differences in investments in human capital lead to differences in activity prices and affect the variety of activities undertaken.

Here an increase in nonlabor income V increases the "effective-time" constraint and has the traditional income effect on variety. Assuming $\mathrm{V}=0$, a wage increase has a pure price effect. It lowers the market-time component $\left(\mathrm{p}_{\mathrm{i}} \mathrm{x}_{\mathrm{i}} / \mathrm{w}\right)$ and changes relative prices in favor of goodsintensive activities. The time released from time-intensive activities may allow the expansion of the activity set and the incorporation of additional goods-intensive activities. An increase in the wage rate in a model where labor supply is exogenous increases the "shadow price" of time and will have a similar effect.

Schooling is associated with increased productivity in the market. It has been argued (Michael, 1973) that it also contributes to productivity at home. If more educated people are more adept at planning, coordinating and streamlining their tasks, then marginal time inputs $t_{i}$ will decline with schooling. Schooling will, therefore, be negatively correlated with shadow prices $\pi_{\mathrm{i}}$ and will increase the variety of activities undertaken. ${ }^{2}$

Nonlinear pricing schemes are relatively rare where the prices of goods are concerned. They are ubiquitous in the world of activity prices. The switch from one activity to the next involves setup costs, either in the form of "unused" time intervals (i.e., "rest" or "waiting") or in the form of transport time (walking or other travel). With the introduction of setup costs (both monetary and time) an equation like (11) in $\bar{\pi}_{\mathrm{i}}$ and $\pi_{\mathrm{i}}$ determines the consumer-producer's decision whether to undertake activity i. These setup costs are usually relatively time-intensive and will therefore tend to increase the cost of the activity to people with a high price of time, causing the wage effect on variety to be more negative. Schooling, on the other hand, will help in coordinating the flow of activities and allow more educated individuals to conserve on "wasted"

\footnotetext{
${ }^{2}$ Schooling may increase the variety of goods consumed independent of any effect on the variety of activities undertaken if more educated people are better suited to undertake complex production processes (processes that involve a large number of products). The issue is whether the impact of schooling on household production technology is neutral or not.
} 
setup time. In this case of nonlinear pricing an activity will be undertaken only if the consumer surplus generated by starting the activity exceeds the setup costs - and schooling should lower setup costs for all activities.

\section{Time-Budgets in Six Countries}

Time-budget surveys in the United States go back at least to Sorokin and Berger (1939). They are relatively scarce worldwide, perhaps because their limited administrative uses reduce funding opportunities for them. Such data are based on daily diaries, but always have to rely on the respondents recollecting at least 24 hours, which limits the length of period covered by the surveys. As a result most time-budget samples are relatively small (not much more than 10,000 respondents) and cover relatively short time periods (up to a week). Given these data constraints and the large variability in survey methods, we adopt a research strategy based on width rather than depth. In the absence of large samples for one country we use the available smaller ones covering six different countries. While this choice is dictated by the small sample sizes available within any one country, this data constraint provides the opportunity to examine the robustness of most of the results by comparing them under the different definitions of variety imposed by the surveys' methods.

The Australian Time Use Survey of 1992 (ABS, 1993) is the second largest of the data sets used here. It is a random stratified sample of roughly 7000 individuals on two days each, with only 1 percent of those who completed a diary on one day failing to provide two days of diary information. The days on which diaries were kept were typically successive, so that the hebdomadal distribution of observations is nearly uniform (and the number of weekend days is thus roughly 40 percent of the number of weekdays). Individuals were asked to list when they began each new activity, and their responses were then coded into 280 separate categories of activities. The activities could encompass as few as 5 minutes, with the upper bound on the length of an activity being the full 24 hours. Moreover, at each point the diary provided space for the respondent to list up to two other activities in which he or she was engaged. In addition to the 
individuals' time diaries one person in each household responded to an interview survey detailing the household's characteristics.

The Israeli Time Use survey was conducted in November 1991-April 1992 (CBS, 1995). It covered 3081 Jewish Israelis who reported their activities on 4840 days. The survey is based on self-recorded diaries (covering about one-quarter of the days) and recall diaries based on interviews. 1712 people reported only one day, 994 - two days, and the rest three (or even four) days. The day was divided into fifteen-minute intervals (except for thirty-minute intervals between 12:30AM and 4AM), and respondents were asked to report the main activity (out of a list of 87) they were engaged in during each interval. Thus unlike in the Australian data activities that might be regarded as secondary (e.g., listening to the radio) may suffer from underreporting, as will may short-duration activities (less than 15 minutes).

The Dutch Tijdbestedingsonderzoek (NIWI, 1993) is a quinquennnial cross-section timebudget study that has been conducted since 1970. In our analysis we use the survey conducted in October 1990, in which 3415 individuals completed usable diaries of their activities. The survey divided respondents into two roughly equal groups, with individuals in one half-sample completing diaries for seven consecutive days (Sunday through Saturday) in one week, and the other half-sample doing so in the second week. ${ }^{3}$ Each individual listed the activity engaged in at each quarter-hour of the previous day. The range of possible activities encompasses 203 separate usable categories. ${ }^{4}$ As in the Israeli sample, no secondary activities are reported.

The 1993-94 Swedish Time Use Survey (Flood, 1997) contains time diaries completed by roughly 4000 respondents to a household interview study. Sample respondents were randomly

\footnotetext{
${ }^{3}$ For half the sample the Sunday included the day when the Netherlands went off summer time. Thus for those individuals on that day there were 1500 total minutes, a difference for which we account in all the following empirical work using this sample. The effect on human activity of this temporary relaxation of the time constraint is analyzed in Hamermesh (2001).

${ }^{4}$ Even this number is the result of combining all newspapers, each of which is listed separately, into one activity, and doing the same for all magazines.
} 
allocated (non-holiday) days over a twelve-month period, with weekend days accounting for nearly half the sample days. A total of 72 activities could be listed; and each respondent could list a secondary activity for any time interval. As in the Australian data, the diaries allowed respondents to indicate at five-minute intervals that they began a new activity.

There have been no large-scale national time-use surveys in the United States since 197576 (reported in Juster and Stafford, 1985). Several sociologists led by John Robinson (see Robinson and Godbey, 1999) have, however, occasionally obtained time diaries from American respondents; and the Americans' Use of Time 1985 survey was large enough (nearly 5000 respondents) to provide the kind of variation needed here. Each respondent filled out one retrospective (day-after) diary of his/her activities, listing activities at no shorter than fifteenminute intervals, with only one activity listed per time period. A total of 87 activities was possible, essentially the same coding as in the Israeli survey. The hebdomadal distribution is almost uniform.

The 1991-92 German Zeitbudgeterhebung (Statistiches Bundesamt, 1999) covered both West and East Germany and was structured quite similarly to the Australian survey. It allowed for large numbers of possible activities and time units disaggregated to five-minute intervals, as well as for secondary activities. The sample is slightly larger than the Australian sample, making this the largest of the six data sets used here. Essentially no one failed to fill out diaries for both days. Because the survey was undertaken very shortly after the German reunification, we use only observations from the former West Germany.

Given the short time spans covered by the surveys, the observations on time allocation are susceptible to nonrandom variation. The major sources of such variation are institutional arrangements relating to work schedules. In all the countries except Israel behavior on Saturdays and Sundays is likely to differ from that on the weekdays Monday through Friday. (In Israel Saturday is a "free" day and Friday is at most a "short" workday, so that we treat Friday and Saturday as the weekend there.) Because of these differences we pay some attention to how 
behavior differs on weekdays and weekends and use these differences to shed light on the theoretical discussion.

Not all the "completed" time diaries are complete for our purposes. In most of the countries one of the activity categories was something like "no activity coded." In order to avoid contaminating the results we discarded any diary-day that included a time interval for which no activity was coded. In the Swedish study this accounted for 12 percent of all days, but in the others the losses were tiny. The age distributions of the respondents differ across the samples; but all the surveys included individuals between ages 18 and 69 inclusive, so that we restrict all the samples to that age range. Finally, because marital status is likely to be crucial in determining behavior, and because the samples of unmarried individuals are often quite small, all of our analyses are restricted to married persons. ${ }^{5}$

Educational systems obviously differ among the five countries, to the point even that years of schooling are not always comparable across the samples. Accordingly, we rely on the respondents' reports of the level of schooling obtained (e.g., in the United States less than high school, high school, more than high school), dividing each sample into three educational categories, with the sizes of the low-, middle- and high-education groups varying across the samples. For each country we inferred the appropriate aggregations from conversations with people who had gone through the educational system. ${ }^{6}$

The theoretical model focuses on three key economic variables: resources, prices and productivity. To separate their effects one needs accurate and detailed data on unearned income, wage rates and factors contributing to productivity at home. Most researchers using time budgets

\footnotetext{
${ }^{5}$ In the Swedish data marital status also includes information on whether the individual is a cohabiting partner. We performed all the analyses in this study on samples of both married and cohabiting partners, with results that differ little from those presented in the text.

${ }^{6}$ For Israel and the U.S. we relied on our own experiences. We are thankful to Damien Eldridge for information on Australia, Gerard Pfann for the Netherlands, Anders Klevmarken for Sweden and John Haisken-De New for West Germany.
} 
are not that fortunate. Time-budget surveys channel most of their effort to the collection of the time diaries, and relatively little is done to assure the quality of the income and earnings data, measures that are prone to substantial response errors even in the best of circumstances (Bound et al, 1994).

None of the surveys contains direct observations on wage rates. One could impute these data indirectly from information on personal earnings and market work time in several of the data sets, but measurement errors and selectivity biases dominate the results. There are no usable wage or income data in the American sample, and the Dutch data on this are extremely weak. For Israel we use the variable "family income, personal earnings excluded," which should provide estimates of pure income effects. The Australian sample provides good measures of family income, but the data on personal incomes include both earnings and nonlabor income. We thus form a measure similar to that for Israel, except this one includes all income accruing to other household members. The measure may be contaminated, because it excludes the respondent's nonlabor income, but it should enable us to exclude own-price effects in the estimates. In the West German data information on both spouses' incomes is available, so that we use spouse's income to proxy the other income available to the respondent. In the Swedish data we use the respondent's gross hourly earnings, so that this market price measure will confound substitution and income effects (and will, of course, also be characterized by selectivity problems).

The only other variables used consistently in the regression analyses are measures of the ages and numbers of children in the married persons' households. Our general rule is to include measures of the number of children and indicators of the age of the youngest child. These latter necessarily differ in definition across the samples; but we can classify them generally as indicating whether the youngest child is pre-school, pre-teen or a teenager (although in one country, Australia, youths over age 14 are not included as children in the data set). Where meaningful additional demographic information is available, it is also included. Thus in the Israeli data indicators of the presence of health problems are included; and in that and the 
Australian samples indicators of country of origin and metropolitan residence are available. In the Australian data we also include information on whether the respondent speaks a foreign language at home.

The analysis deals with consumption activities. Work, in the market or at home, usually involves multi-task activities. These tasks are, however, often dictated by outside factors (i.e., the employer) and the nature of the job. Moreover, most time-budget studies report home activities in detail, while market activities are only reported in aggregate terms (i.e., primary job, secondary job, etc.). The distinction between consumption and work activities is not always easy, especially where work at home is concerned. Psychic income (i.e., direct utility derived from the activity) is sometimes an important consideration affecting the decision about how much time to spend on a household-work activity. This is particularly true for such borderline cases as child-care activities. Recognizing, however, the need to distinguish work from nonwork activities, throughout this study we define work as including market work, cleaning and cooking at one's residence, and shopping, with nonwork encompassing all other activities.

In analyzing time use, as opposed to its diversity, we distinguish among several types of nonwork activity, including child and family care, personal care and "leisure" activities. Both of the latter are mainly consumption activities in terms of Becker's model, but we expect the variation in time spent in personal care to be smaller than that in leisure. We thus examine the determinants of time spent on each of these three types of nonwork activity. ${ }^{7}$

For each respondent-day the central concept in this study is the number of different nonwork activities in which the individual is engaged on that day. We focus on the variety of

\footnotetext{
${ }^{7}$ The level of disaggregation is clearly limited only by the number of fundamental activities coded from the diaries (shown in Table 1). Choices in the (sparse) economics literature have varied from seven in Kooreman and Kapteyn (1987) to three in Biddle and Hamermesh (1990), compared to our five (market and home work and the three categories of nonwork activity).
} 
nonwork activities and present all results for this set of activities. ${ }^{8}$ The minimum number of activities that we observe in the five samples on a diary-day is one, while the maximum possible is the number of nonwork activities that could be coded (from 40 in Sweden to 202 in Australia). Even in Australia, however, no respondent reported more than 32 different nonwork activities on a single day.

For comparison purposes Table 1 summarizes most of the essential characteristics of the six samples that underlie this study. ${ }^{9}$ In addition to the characteristics of the data already discussed we note the number of possible nonwork activities in each sample. The table illustrates the diversity of the samples in terms of the numbers of possible activities, the range of days on which diaries were obtained, and the degree of temporal disaggregation possible in the diaries.

\section{First Impressions}

\section{A. The Allocation of Time Among Activities}

Although a substantial sociological literature has generated tabulations of time spent on different activities (see, e.g., most of the articles in Merz and Ehling, 1999, and the references therein), with much of the focus on sex differences, there are several reasons for reexamining such tabulations here. Most studies examine only one country's data, obviating the chance to discern general, possibly universal patterns. Thus we may learn something about general differences in the allocation of time by sex if we examine time allocation in six countries using exactly the same methods and definitions. Second, and more important, we cannot understand

\footnotetext{
${ }^{8}$ For the Israeli and Dutch data, on which we experimented before adding the other four data sets, we estimated equations describing variety along these other dimensions, both broader and narrower. The results for the narrower set of categories, leisure activities, including the results on our measures of schooling, were qualitatively very similar to those reported in the text for the measures of variety in nonwork activities. For the total of all activities the results were somewhat stronger, mainly because the additional schooling is associated with more time in market work. Excluding child and family care activities also does not alter the results qualitatively, nor does excluding transportation activities.

${ }^{9}$ The numbers of observations actually used in the analyses are presented in the tables showing regression results. These fall far short of the total sample sizes due to the restrictions on age and marital status, and to missing variables on both the respondents' characteristics and in the diaries themselves.
} 
the production of variety unless we know the context of time use in which it is produced. The analysis of time use presented in this subsection is based on Tables $2 \mathrm{a}$ and $2 \mathrm{~b}$, which list the mean minutes per day allocated to market work, home work, childcare, personal care and leisure separately by sex and schooling level for each of our six samples. Each statistic is presented for a "representative day" - a weighted average of the observations in each cell that reflects the average allocation of time across weekdays and weekends.

Consider first the sex differences in time allocation demonstrated by comparing results between Tables $2 \mathrm{a}$ and $2 \mathrm{~b}$. The data replicate most of the well-known sex differences, including greater market work, less home work and less childcare by men. The greater allocation of time in personal care by women is less well known, but it reproduces findings for the U.S. by Biddle and Hamermesh (1990) on sleep, by far the largest component of personal care. The bottom row for each category of individuals shows the total nonwork time (childcare, personal care and leisure). In all six countries men's greater market workhours more than compensate for their lesser time spent in home work, so that total nonwork time is less among men than women. Much less well known are the differences in leisure time between men and women. In Australia and the United States the differences in leisure time by sex are essentially zero; but in the other four countries married men consume more leisure than do married women. The sex differences in leisure time are opposite those in time spent on personal care, with the total of leisure time and personal care typically about the same by sex or slightly lower among men.

Even within these gender differences there are some international differences that are enlightening. If one examines the sex ratios of time spent on market work, home work and childcare, Sweden has the greatest degree of equality in all three categories. Swedish women's time use is more like that of men than is true of women elsewhere. This similarity is not only in Swedish women's well-known (OECD 2000, Table B) attachment to the labor force, but also in their nonmarket work and childcare. Also striking is the consistently lower consumption of leisure by Americans - both married men and married women. The data make it clear that 
Americans' relatively long market workweeks are not fully offset by reductions in home work, personal care or childcare. That Germans consume even less leisure is due to their relatively high reported time spent in home work.

The effect of schooling on time spent in market work, mainly through its effect on wages and then on labor supply, is one of the best-established facts in labor economics. It is replicated here for all countries and both sexes. Among women the positive relation between schooling and market work is accompanied by a negative relation between home work and schooling. Among men the home work-schooling relationship is slightly negative or zero, so that the effect of schooling on total work is less than is indicated by its effect on market work alone. As a result, in all countries but Germany, and for both sexes, there is a nonnegative schooling - total work gradient. This means that the total amount of time available for nonwork activities, and thus the possibility of generating more diversity in nonwork activities, is less among more educated people in five of the six countries.

The implied non-positive correlation between nonwork time and schooling is further borne out by the results of the detailed regression analyses presented in the Appendix (where even in Germany there is essentially no partial relationship). The estimates also reveal a U-shaped relationship between nonwork time and age (reflecting the age-market work profile), a negative effect of preschool children on their fathers' nonwork time and a positive effect on their mothers' nonwork time (not reported in the Appendix). The income effects, estimated for Australia, Israel and West Germany are generally negative but small, corroborating the often incorrectly-signed impacts produced in the few previous studies that examine these issues using time-budget data (e.g., Kooreman and Kapteyn, 1987; Biddle and Hamermesh, 1990).

\section{B. Variety of Activities}

Table 3 presents the means and their standard errors of the number of nonwork activities undertaken on a representative day by the married respondents in our six samples. Remembering the international differences in the number of possible activities in the surveys, these tables make 
it quite clear that, where more activities are possible, more activities are coded as having been undertaken. Australia, the Netherlands and West Germany, which have at least twice as many possible nonwork activities as the other countries, show higher mean numbers of activities performed than do the other countries. Australia, which had the most possible activities, is highest, while Sweden, which had the fewest possible, is lowest. The international differences, however, are not huge and are far less than proportional to the differences in the number of possible activities. Comparing men and women, the most striking difference is that women engage in more nonwork activities than do men. ${ }^{10}$ Looking at the sources of variety, it is clear that the gender difference stems from women's undertaking more child-care related activities.

One of the central hypotheses of this study is that additional schooling generates greater household productivity in the form of the ability to produce more variety. Comparing the mean consumption of variety across schooling level provides an initial look at this hypothesis. For both sexes we find a general rise in the number of different nonwork activities undertaken as the level of education rises (even though in most of our data sets better educated people have less time available in which to undertake nonwork activities). The only exception is for men in Sweden. Whether because of a causal relation between schooling and efficiency in household production, or because people with a greater taste for variety that is not captured by their observable characteristics invest more in human capital, is unclear from these descriptive statistics; but the existence of this positive simple correlation is abundantly clear from this six-country analysis.

\section{Detailed Analysis of the Demand for Variety}

While some interesting patterns are apparent in the means presented in Table 3 , it is unclear whether these are true partial effects. In several of the countries schooling attainment,

\footnotetext{
${ }^{10}$ In Australia the total number of different activities, including secondary activities, is 9.51 for men and 10.30 for women in Sweden, 8.09 and 8.56, and in West Germany, 10.51 and 11.77. Including reporting of secondary activities adds almost nothing to our measure of variety in the Australian data, and not a huge amount even in the Swedish data. (In the Australian data the amount of time in which secondary activities are coded is only 5 percent of the day among men and 6 percent among women. In the Swedish data the comparable percentages are 27 and 28, while in West Germany the percentages are 90 and 91 respectively.)
} 
our central focus, is highly negatively correlated with age, confounding its effects with those of aging. In all but Sweden there is also a significant negative correlation between education and family size, holding age constant. We thus present regression estimates of the impacts of the education, age and family structure measures on variety. Throughout this section we list robust standard errors that account for the multiple observations (diary-days) included for most of the respondents in all but the American data sets. The sample sizes listed indicate the number of different individuals included in the regressions. All the estimates are for a representative day.

The central results of this study are contained in Tables $4 \mathrm{a}$ and $4 \mathrm{~b}$, which list the parameter estimates from regressions describing the respondents' demand for variety (measured as the number of nonwork activities undertaken). Estimates of the determinants of the number of nonwork activities are shown only for variables measuring schooling, age and the age and numbers of children; but each equation also includes indicators of the day of the week (since there may be differences across the days in the cost of generating variety). Other controls (discussed in Section III) are also included where available. ${ }^{11}$

Additional schooling has a generally positive partial effect on the number of different activities undertaken each day. This is true for each transition to a higher education group for both men and women in the Australian, Israeli, Dutch, American and German samples. Only in Sweden is there no evidence of any impact of additional schooling on the amount of variety produced. $^{12}$ Given the generally positive relation between schooling and market work time,

\footnotetext{
${ }^{11}$ In many cases the vectors of coefficients of the indicators of day of week were statistically significant, but there was only one regularity in the results across the samples (excluding Israel): In many of the estimates describing activities more variety was produced on Sunday than on Saturday.

${ }^{12}$ This anomalous result is not due to the correlation of age and educational attainment in the Swedish data. When the equations are reestimated on subsamples divided at age 45 the same results are found. Similarly, a different definition of the educational categories that also seemed consistent with the classification of workers into thirds did not alter this conclusion. It is also probably not due to the relatively high level of aggregation of activities: Aggregating activities in the American data to match the Swedish definitions as closely as possible (leaving 39 activities in the American data) did not alter the signs or significance of the impact of educational attainment on the amount of variety generated. One other possibility is simply that differences in the impact of education on household productivity are less there than elsewhere. While it is true that the relationship between educational attainment and literacy scores is flatter in Sweden than in the
} 
finding an effect of schooling on variety is an extremely strong result, as the more educated generally have less available nonwork time (as shown in Tables 2) in which to undertake more variety in their nonwork activities. ${ }^{13}$ Whether this results from the pure relationship between schooling and efficiency in household production, or from the correlation between schooling and the price of time, cannot be inferred from these estimates alone.

One might argue that the results on schooling are an artifact stemming from the ingenuity of more educated respondents in listing more varied activities in their diaries. We cannot fully refute this; but if it were true, we would expect to see bigger effects of schooling in those samples in which more possible nonwork activities might be listed (Australia, the Netherlands and West Germany). That the marginal effects of moving to a better-educated group are roughly the same in the Israeli and American samples (where the time diaries provided for many fewer possible nonwork activities) as in these other three samples suggests the result is not spurious. ${ }^{14}$

One might also argue that the requirement that an activity lasts at least 15 (or 5) minutes for it to be recorded causes us to underestimate the amount of variety consumed. Of course it is true that extremely short-duration activities are not included in the data. There is no reason, however, for this lacuna to imply that our measure of variety is severely biased downward, as many such activities are undertaken for longer periods at other times in a day (e.g., a quick handwashing and a thorough night-time clean-up, a brief glance at the Weather Channel and a half-hour sitcom, etc.). Also, there is no reason for their exclusion to affect reporting United States, this is also true in the Netherlands and Germany (Devroye and Freeman, 2001). A final possibility is that, because the Swedish earnings distribution is more compressed than in the other countries, negative wage effects on variety bias downward the estimated impact of education.

${ }^{13}$ Unsurprisingly, given that the measure of variety increases only slightly in the Australian data when we include secondary activities, reestimates of the equations in Tables 4 including secondary activities look almost identical to those presented in the Tables. Even though measured variety increases somewhat in the Swedish and substantially in the West German data when secondary activities are included, the impact is almost entirely on the estimated intercepts. The schooling and other estimated parameters change very little.

\footnotetext{
${ }^{14}$ Each of the surveys was also extensively pre-tested, in part to ensure that respondents were able to express their activities consistently. This provides some additional assurance that the questionnaire biases are small.
} 
differentially by level of education. Indeed, if our theory is correct, the underreporting will be greater among the more educated, since it will be easier for them to produce the extremely shortduration activities that are not recorded. Regardless, observing educational effects of roughly the same sizes in Australia (and West Germany) and the Netherlands, which have similarly large numbers of possible activities but different minimum possible time intervals, suggests that these results are not an artifact of constraints on the minimum duration of recordable activities.

Except for Australian and Dutch women the impact of age on variety is U-shaped, superficially quite inconsistent with the human capital theory of earnings and with a view that efficiency increases over much of one's adult life. A more thorough examination shows that in most cases the estimates do suggest exactly that kind of increasing effect. In the American, Israeli and West German samples and among Dutch and Swedish men the amount of variety produced is increasing over the large majority of the range of ages included in the samples. ${ }^{15}$

Having more children in the household increases the number of activities undertaken, other things equal, in all of the samples analyzed here. For both sexes the presence of pre-school children adds substantially to the amount of variety produced, while having pre-teen children adds to it somewhat. Taken together the results suggest, however, that couples whose youngest child is a teenager produce less variety than do childless couples. While the impact of pre-school children on variety holds for both mothers and fathers, its magnitude is far larger among mothers. Children generally, and pre-school and pre-teen children in particular, clearly add to the variety of activities produced by the household, with most of the additional variety produced by mothers in childcare activities.

The equations presented in Table 4 do not include the measures of income and/or earnings that are present in the data sets describing four of the six countries we analyze. They were excluded because we believe that they are much noisier than the other variables in those

\footnotetext{
${ }^{15}$ Not surprisingly, these estimated impacts and those of schooling are much stronger, especially among men, if we include the amount of time devoted to market work as an independent variable.
} 
regressions and because they are missing for two countries. Nonetheless, it is worth examining their impacts on the production of variety, as they are part of what is central in our theoretical motivation. Table 5 lists the estimated coefficients of regressions like those in Tables 4 , with the equations expanded to include the available income and earnings measures. The first thing to note in these tables is that our inferences from Tables 4 on the impacts of education and age are qualitatively unchanged when these monetary measures are added to the estimating equations.

In the Australian, Israeli and West German data the estimates demonstrate either that variety is a superior good, or that there are positive cross-wage effects in the demand for variety. For all three countries and both sexes more variety is purchased by individuals who are in households whose other members have higher incomes. The impacts are not very large. Doubling other income in the Australian samples leads to increases in the number of activities of only 1 percent; in the Israeli samples variety increases by 3 percent; and in West Germany variety increases by less than 1 percent among men, but by 4 percent among women. In the Swedish data, the only sample for which we can use a measure of hourly earnings, the generally negative impacts of hourly earnings suggest that substitution effects predominate in the impact of higher time prices on the demand for variety.

Another way of considering the relation between education and variety notes that equation (11) implies that increased efficiency in household production (or additional unearned income) leads to an expansion at the extensive margin of activities. (A noneconomic prediction would merely be that education alters people's tastes, and by expanding their horizons allows them to undertake more activities that may or may not include those undertaken by less educated individuals.) We should expect that less educated people will not only engage in fewer activities, but that their activities will be a subset of those undertaken by individuals with more education. If it applies perfectly, this "enveloping" property should lead to higher fractions of more educated people undertaking each activity. 
Even if the enveloping hypothesis is correct, sampling variation means that we will never observe higher fractions of the more educated in all activities. We can examine the hypothesis for all five countries for which the evidence in Tables 3-5 showed that variety rises with education for both men and women. The fractions of activities in which the more educated group participates more than the less educated group are shown in Table 6 for both sexes, for each country, and for each of the three possible two-way comparisons. In all but two of the thirty comparisons, the two involving highly-educated Australian women, the fraction in which representation by the more educated group predominates exceeds the ratio $A_{M} /\left[A_{L}+A_{M}\right]$, where $A_{M}$ is the mean number of activities undertaken by members of the more educated group, and $A_{L}$ is the mean among the less educated group. The evidence thus suggests that the enveloping hypothesis is correct: More educated people include the activities of the less educated as a proper subset of the activities that they undertake.

\section{What Kind of Variety?}

\section{A. The Duration of Activities}

The increase in variety with the number of pre-school children and the U-shaped effect of age (at least in the case of males) do not create any puzzles, since they closely trace the effects that these variables have on total nonwork time. The impact of schooling cannot be explained in the same way, since nonwork time is at most unaffected by schooling and in many cases diminishes as schooling (and market work time) increases.

The theory predicted that variety will increase with schooling due to two effects: 1) Increased home productivity allows the more educated to squeeze more activities into the same amount of time, and higher wages result in relatively lower "time costs" of the more goodsintensive activities for them; and 2) More educated individuals substitute from time-intensive to goods-intensive activities. As the wage increases, the lower the elasticity of substitution between time and goods, the greater the increase in the relative price of time-intensive activities. Sleep is 
the most time-intensive activity, and there is very little chance to substitute goods for time in its production. It is, therefore, the prime candidate for cuts when wages increase (Biddle and Hamermesh 1990). Partial support for this hypothesis can be found in the observed pervasive negative relationship between schooling and time spent on personal care (most of which is sleep) shown in Table 2 (and in the regression results in the Appendix).

More details are provided by Table 7, which presents the distribution of activities by their duration (total minutes spent in the activity on a representative day) for men and women, both in total, and distinguished by educational attainment. The table demonstrates the skewness of the distribution of activities by duration. About half of the activities (between 45 and 60 percent) last less than an hour, between 30 and 40 percent last more than an hour but less than 4 hours, and one activity, almost always sleep, lasts more than 6 hours. The percentage of people who sleep more than 8 hours on an average day declines with schooling. Similarly, in the $1-4$ hour activity group the number of long activities (2-4 hours) diminishes and the number of short activities (1-2 hours) increases as schooling increases. The time saved allows a 30-40 percent increase in the number of very short, i.e., less than one hour, activities (with Sweden again the exception). ${ }^{16}$

\section{B. Routine vs. Nonroutine Activities}

The large fraction of time spent by the less educated on the more time-intensive activities - sleep, rest and TV watching - that have only a very small (variable) goods component, is indicative of the presence of slack time. The less educated have enough time at their disposal, but do not possess the material resources that allow them to diversify their set of activities. The opposite holds for the more educated - they have already conserved on all the time-intensive activities, and the major constraint on the diversification of their daily activities is the time constraint. The only way open to them to diversify their activity set is by diversifying

\footnotetext{
${ }^{16} \mathrm{~A}$ more detailed examination indicates that two other time-intensive activities—-rest and TV watchingare (besides sleep) responsible for the release of time that allows the proliferation of short-duration activities among the more educated.
} 
among days. Thus, if one compares the daily activity sets across days, we should expect a greater similarity among the less educated than among the more educated.

To test this hypothesis, we compare activity sets between days in those samples where people reported two days of activities (i.e., all countries except the Netherlands and the U.S.). Routine activities are defined in the two-day samples as those activities that were undertaken on both days, and nonroutine activities are those that were undertaken only on one of the two days. Let NACTW be the number of different activities in which the respondent engaged over the two reported days:

$$
\min \left(\mathrm{NACT}_{\mathrm{i}}\right) \leq \mathrm{NACTW} \leq\left[\Sigma \mathrm{NACT}_{\mathrm{i}}\right]
$$

where $\mathrm{NACT}_{\mathrm{i}}$ is the number of different activities undertaken on day i. We define the number of routine activities as:

$$
\text { ROUTINE }=\Sigma \mathrm{NACT}_{\mathrm{i}}-\mathrm{NACTW} .
$$

The number of nonroutine activities is:

$$
\text { NONROUTINE }=\text { NACTW }- \text { ROUTINE } .^{17}
$$

Estimates of the mean numbers of routine and nonroutine activities undertaken in each of the four samples in total and by level of education are shown in Table 8 . In all four, and for both men and women, the number of nonroutine activities undertaken rises with education. Even for Swedish men, among whom the total number of activities did not generally rise with education, most of the anomalies appear to be due to unexpected differences in the number of routine activities. Variety in routine activities increases with education in the Australian and West German samples, and among Israeli women, but those increases are much less pronounced than the increases in nonroutine variety. ${ }^{18}$

\footnotetext{
${ }^{17}$ Only those Israelis on whom we have exactly two diary-days are included in this analysis.

${ }^{18}$ While the Dutch data are not comparable, we can use them analogously by defining: ROUTINE $=\left\{\Sigma \mathrm{NACT}_{\mathrm{i}}-\mathrm{NACTW}\right\} / 6$.

Using this definition (for which we thank Roberton Williams), we find that the gradient in routine activities is flatter with respect to education than that in nonroutine activities. Not only does this result corroborate
} 
Tables 9 present estimates of the impacts of schooling, age and the number and ages of children on the demand for variety in both routine and nonroutine nonwork activity. For each country the first column shows the estimates for variety in routine activities, and the second lists results for variety in nonroutine activities. The most striking finding, one that is consistent across all four samples and for both sexes, is that the impact of schooling on variety is mainly on the production of variety in nonroutine activities. This was true of the means presented in Table 8, but the results holding other factors constant are even stronger. Indeed, in the Australian, Israeli and West German data, where the average numbers of routine and nonroutine activities undertaken differ little, the impacts of higher educational attainment are roughly twice as large on variety in nonroutine than in routine activity. Among Swedish women the impact of schooling on routine variety is negative (with coefficients in excess of their standard errors), while the impact on nonroutine variety is positive, with the higher two education groups producing significantly more variety than the lowest. Additional schooling is related to greater household productivity; but it is along the margin of activities that are not routine-for which the possibility of technological improvement generated by additional education may be greater - that the relationship is most noticeable. ${ }^{19}$

Detailed regressions focusing on the variability of personal care activities (most of which are routine) and leisure activities (which have a large nonroutine component) indicate that increased schooling is associated with an increase in leisure activities but hardly affects the number of personal care activities. The time conserved in personal care activities (most notably

the evidence in Table 7; it also shows that, when we can examine variety in consumption over a time interval longer than two days, we still find the same difference in the relationships between education and routine and nonroutine variety.

${ }^{19}$ The equations were reestimated for Australia, Sweden and West Germany to include secondary activities in the definitions of routine and nonroutine variety. Unsurprisingly, given the small fraction of times for which Australians coded secondary activities, the results are nearly identical to those presented in Tables 9 . Even in Sweden and West Germany, however, the impact of education on nonroutine variety remained greater than on routine variety. 
sleep and rest) is used to increase the diversity of nonroutine leisure activities. As with the role of education in implementing technical change in product markets (see Welch, 1970, and an avalanche of recent empirical studies), our results are consistent with the view that education enables individuals to cope better with nonroutine, but has a much smaller impact on routine activities. $^{20}$

\section{Weekday vs. Weekend Variety}

All of the results presented in Section V and the first part of this Section are based on a representative day - an amalgam of time diaries from weekdays and weekends. Yet for our purposes the underlying data are richer than this, since they allow us to examine temporal variations in variety and how these are affected by differences in human capital. The additional information provided by regressions here is small, so to save space we present descriptive statistics only.

Table 10 shows the means and their standard errors of the number of activities undertaken. The first number in each pair is for the average weekday, the second for the average weekend day. Except for Australians of both sexes and for Swedish and West German women there is more variety in nonwork activities on weekends than on weekdays. To a large extent this is due to the fact that work (in the market especially) leaves less time for variety on weekdays, as suggested by the much smaller weekday-weekend differences in variety among women than among men. The striking fact from this table is that the increase in variety with educational attainment is present on both weekdays and weekends, and indeed is slightly greater on weekends than on weekdays. If the schooling-variety gradient were due simply to the correlation between schooling and the value of market time, the relationship would break down on weekends, when the schooling-value of time relationship is presumably weaker because market work opportunities are less. That this breakdown does not occur suggests that the schooling-variety link that we have

\footnotetext{
${ }^{20}$ Among both men and women, having additional children generates more variety; but in all four countries substantially more of the extra variety is in the number of nonroutine activities.
} 
demonstrated reflects not only a wage effect on the demand for variety, but also an efficiency effect as schooling raises people's ability to overcome setup costs.

As an additional step we examine the schooling-variety result in more detail by comparing differences in the gradient between people whose two days of time diaries cover one weekend day and one weekday and the other respondents, both of whose diaries are on weekend days or weekdays only. If schooling is productive we should expect to observe a sharper gradient of variety in nonroutine activities among respondents in the former group, since more educated people will be better able to take advantage of the absence of constraints on their time on weekends to generate more different activities. We are thus essentially estimating the double difference:

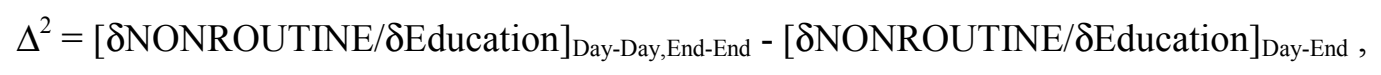

in the impact of schooling on variety-comparing across the two diary-days and across the two categories of respondent. If education affects variety causally, we will observe $\Delta^{2}<0$.

We can reestimate the models in Table 9 describing nonroutine variety only for Australia and West Germany, as these are the only countries where the sampling procedure generates enough observations with diaries on both weekends and weekdays. Using the coefficient estimates on the indicators of educational attainment, we estimate $\Delta^{2}=1.34-2.18=-0.83$, and $\Delta^{2}=0.97-1.60=-0.63$ for men in Australia and West Germany respectively. Among women the estimates are $\Delta^{2}=1.02-1.28=-0.26, \Delta^{2}=1.09-1.26=-0.17$ in the two countries respectively. For both sexes and both countries the schooling-nonroutine gradient is steeper when we observe people on whom time constraints differ across the two days sampled. That more educated workers have more flexibility in their work time, so that a pair of weekdays that might seem to be equally restrictive is less constraining for them, means that, if anything, the estimates of $\Delta^{2}$ have a positive bias, so that the true double differences are even more negative. 


\section{Conclusions and Implications}

We have constructed a model of household production focusing on variety in the household members' undertakings. Driving the model are differences among households in the ability to overcome the setup costs that occur when time (and perhaps monetary) resources must be devoted to adding a new activity to the set of activities undertaken in the day or week. We postulate that those differences are linked to schooling and its positive relationship to the efficiency of the household's production technology. Using time-budget surveys from six countries we have demonstrated that this is exactly what occurs: Individuals with more education undertake more different activities in a day. Moreover, these differences stem mostly from the ability of more educated people to generate a greater variety of those activities, which we call nonroutine, that are not repeated every day. One can also infer from our model that incomes and the price of time will affect the amount of variety undertaken. We do observe positive pure income (or cross-wage) effects in the three countries for which we have data, and for the only country on which we have wage data there is weak evidence that substitution effects dominate.

One can interpret the variety-schooling relationship as causal, although the evidence on the relationship between education and the total variety of activities might by itself also be construed as reflecting underlying heterogeneity among individuals and households. That we observe different relationships between education and routine versus nonroutine variety and similar variety-schooling gradients on weekdays and weekends are harder to explain by underlying heterogeneity, but reasonable explanations might possibly also be constructed on that basis.

Education produces a remarkable variety of benefits, from direct effects on earnings (Becker, 1964), to externalities that it creates in production and the spillover to economic growth (e.g., Romer, 1986), to impacts on noneconomic outcomes such as criminal activity and others (e.g., Grogger, 1998). We have suggested here that education generates yet another welfareenhancing outcome - additional variety in the activities in which people engage. We cannot 
measure the magnitude of the gain in welfare that is generated by the greater diversity in activities that comes with education. ${ }^{21}$ All that can be concluded at this point is that there are gains along this dimension, with the effect of education on variety not small: Except for Sweden the estimates suggest that each extra year of schooling yields around a 2 percent increase in variety.

Having demonstrated that there are systematic differences among households in the production of variety, one wonders how this realization might affect the theory of product demand. The first thing to do here is to analyze whether greater variety in time use is associated with greater variety in the kinds of goods used in household production. Even without that analysis, however, these results suggest that, as its citizens acquire more skills, an economy will generate a greater demand for variety in the activities that its consumers undertake and will provide incentives for greater differentiation of the products that its firms offer. This development will in turn affect the structure of product markets.

\footnotetext{
${ }^{21}$ The issue is somewhat similar to that of valuing new goods (see Hausman, 1997), although the welfare effects of increased variety are generated endogenously rather than by a presumably exogenous product innovation.
} 


\section{REFERENCES}

Australian Bureau of Statistics, Time Use Survey, Australia 1992. Canberra: ABS, 1993.

Gary Becker, Human Capital. New York: Columbia University Press, 1964.

--------, “A Theory of the Allocation of Time,” Economic Journal, 75 (September 1965): 493-517.

Jeff Biddle and Daniel Hamermesh, "Sleep and the Allocation of Time," Journal of Political Economy, 98 (October 1990): 922-43.

John Bound, Charles Brown, Greg Duncan and Willard Rodgers, "Evidence on the Validity of Cross-sectional and Longitudinal Labor Market Data," Journal of Labor Economics, 12 (July 1994): 345-68.

Central Bureau of Statistics, “Time Use In Israel--Time Budget Survey 1991/92," Special Series No. 996. Jerusalem: CBS, 1995.

Edward Chamberlin, The Theory of Monopolistic Competition. Cambridge, MA: Harvard University Press, 1933.

Dan Devroye and Richard Freeman, "Does Inequality in Skills Explain Inequality of Earnings Across Advanced Countries?" Working Paper No. 8140, National Bureau of Economic Research, February 2001.

Avinash Dixit and Joseph Stiglitz, "Monopolistic Competition and Optimum Product Diversity," American Economic Review, 67 (June 1977): 297-308.

Lennart Flood, Household Market and Nonmarket Activities (HUS). Uppsala: Uppsala University, Department of Economics, 1997.

Jeff Grogger, "Market Wages and Youth Crime," Journal of Labor Economics, 16 (October 1998): 756-91.

Reuben Gronau, "Home Production-A Survey," in Orley Ashenfelter and Richard Layard, eds. Handbook of Labor Economics, Vol. 1. Amsterdam: North-Holland, 1986.

-----------, “The Theory of Home Production-The Past Ten Years," Journal of Labor Economics, 15 (April 1997): 197-205.

Daniel Hamermesh, "Timing, Togetherness and Time Windfalls," Journal of Population Economics, (2001): forthcoming.

Jerry Hausman, "Valuation of New Goods under Perfect and Imperfect Competition," in Timothy F. Bresnahan and Robert J. Gordon, eds. The Economics of New Goods. Chicago: University of Chicago Press, 1997.

Laurence Jackson, "Hierarchic Demand and the Engel Curve for Variety," Review of Economics and Statistics, 66 (February 1984): 8-15. 
F. Thomas Juster and Frank Stafford, Time, Goods and Well-being. Ann Arbor: Institute for Social Research, 1985.

Peter Kooreman and Arie Kapteyn, "A Disaggregated Analysis of the Allocation of Time within the Household," 95 Journal of Political Economy, (April 1987): 223-49.

Joachim Merz and Manfred Ehling, eds., Time Use-Research, Data and Policy. Baden-Baden: NOMOS Verlagsgesellschaft, 1999.

Robert Michael, "Education in Nonmarket Production," Journal of Political Economy, 81 (March/April 1973): 306-27.

Nederlands Instituut voor Wetenschappelijke Informatiediensten (NIWI), Tijdbestedingsonderzoek 1990. Amsterdam: Steinmetz Archive, 1993.

Organization for Economic Cooperation and Development, OECD Employment Outlook. Paris: OECD, 2000.

John Robinson and Geoffrey Godbey, Time for Life: The Surprising Ways Americans Use Their Time, $2^{\text {nd }}$ ed. University Park, PA: Pennsylvania State University Press, 1999.

Paul Romer, "Increasing Returns and Long-Run Growth," Journal of Political Economy, 94 (October 1986): 1002-37.

Steven Salop, "The Noisy Monopolist: Imperfect Information, Price Dispersion and Price Discrimination," Review of Economic Studies, 44 (October 1977): 393-406.

Pitirim Sorokin and Clarence Berger, Time-Budgets of Human Behavior. Cambridge: Harvard University Press, 1939.

Statistiches Bundesamt, "Wo Bleibt die Zeit? Die Zeitverwendung der Bevölkerung in Deutschland." Wiesbaden, Germany: Statistiches Bundesamt, 1999.

Finis Welch, "Education in Production," Journal of Political Economy, 78 (January/February 1970): 35-59. 
Table 1. Characteristics of the Six Time-Budget Surveys

\begin{tabular}{|c|c|c|c|c|c|}
\hline $\begin{array}{l}\text { Country and } \\
\text { Year }\end{array}$ & $\begin{array}{l}\text { Number of } \\
\text { Observations } \\
\text { (Original sample) }\end{array}$ & $\begin{array}{c}\text { Days per } \\
\text { Observation }\end{array}$ & $\begin{array}{c}\text { Number of } \\
\text { Activities }\end{array}$ & $\begin{array}{l}\text { Number of } \\
\text { Nonwork } \\
\text { Activities }\end{array}$ & $\begin{array}{l}\text { Interval Length } \\
\text { (minutes) }\end{array}$ \\
\hline $\begin{array}{l}\text { Australia } \\
1992\end{array}$ & 7056 & 2 & 280 & 202 & 5 \\
\hline $\begin{array}{l}\text { Israel } \\
1991-92\end{array}$ & 3081 & $1-4$ & 87 & 64 & 15 \\
\hline $\begin{array}{l}\text { Netherlands } \\
1990\end{array}$ & 3415 & 7 & 203 & 129 & 15 \\
\hline $\begin{array}{l}\text { Sweden } \\
1993-94\end{array}$ & 4121 & 2 & 72 & 40 & 5 \\
\hline $\begin{array}{l}\text { United States } \\
1985\end{array}$ & 4939 & 1 & 87 & 64 & 15 \\
\hline $\begin{array}{l}\text { West Germany } \\
1991-92\end{array}$ & y 10799 & 2 & 230 & 128 & 5 \\
\hline
\end{tabular}


Table 2a. Time Allocation of Married Men by Schooling Level (Minutes per Representative Day)

\begin{tabular}{|c|c|c|c|c|c|c|}
\hline \multirow[b]{2}{*}{ All } & \multirow[t]{2}{*}{ Australia $^{1}$} & \multirow[t]{2}{*}{ Israel $^{2}$} & \multicolumn{3}{|c|}{$\begin{array}{r}\text { Netherlands }{ }^{3} \text { Sweden }^{4} \text { United }^{\text {States }}{ }^{5}\end{array}$} & \multirow[t]{2}{*}{$\begin{array}{c}\text { West } \\
\text { Germany }\end{array}$} \\
\hline & & & & & & \\
\hline Market work & 329 & 382 & 271 & 322 & 336 & 356 \\
\hline Home work & 141 & 74 & 123 & 110 & 136 & 135 \\
\hline Childcare & 23 & 32 & 23 & 17 & 20 & 26 \\
\hline Personal care & 605 & 584 & 627 & 565 & 626 & 621 \\
\hline Leisure & 341 & 368 & 400 & 426 & 322 & 301 \\
\hline Total nonwork & 969 & 984 & 1050 & 1008 & 968 & 948 \\
\hline \multicolumn{7}{|c|}{ Low Schooling Third } \\
\hline Market work & 299 & 242 & 241 & 285 & 285 & 345 \\
\hline Home work & 143 & 105 & 142 & 110 & 145 & 145 \\
\hline Childcare & 20 & 20 & 22 & 13 & 21 & 21 \\
\hline Personal care & 625 & 674 & 643 & 584 & 661 & 628 \\
\hline Leisure & 355 & 399 & 396 & 448 & 328 & 301 \\
\hline Total nonwork & 1000 & 1093 & 1061 & 1045 & 1010 & 950 \\
\hline \multicolumn{7}{|c|}{ Middle Schooling Third } \\
\hline Market work & 343 & 394 & 294 & 330 & 336 & 359 \\
\hline Home work & 143 & 71 & 118 & 108 & 131 & 127 \\
\hline Childcare & 22 & 29 & 20 & 21 & 20 & 29 \\
\hline Personal care & 599 & 584 & 622 & 560 & 621 & 621 \\
\hline Leisure & 333 & 362 & 391 & 421 & 332 & 304 \\
\hline Total nonwork & 954 & 975 & 1033 & 1002 & 973 & 954 \\
\hline \multicolumn{7}{|c|}{ Top Schooling Third } \\
\hline Market work & 359 & 409 & 294 & 370 & 354 & 367 \\
\hline Home work & 136 & 67 & 109 & 112 & 135 & 129 \\
\hline Childcare & 35 & 38 & 28 & 19 & 20 & 31 \\
\hline Personal care & 578 & 560 & 615 & 541 & 619 & 613 \\
\hline Leisure & 332 & 366 & 397 & 397 & 311 & 299 \\
\hline Total Nonwork & 945 & 964 & 1040 & 957 & 950 & 944 \\
\hline
\end{tabular}

NOTE: Here and in Table $2 b$ the total minutes allocated may differ slightly from 1440 due to rounding. In the Netherlands, however, the totals differ substantially due to the inclusion of the roughly half-sample whose Sunday timediary was kept for the 1500-minute day.

\footnotetext{
${ }^{1}$ Low if secondary or no qualifications; middle if a certificate, diploma or trade qualified; high if a bachelor's degree. The distribution is: 38 percent, 46 percent and 16 percent.

${ }^{2}$ Low if $0-8$ years; middle if 9-12 years; high if $13+$ years. The distribution is: 13 percent, 43 percent and 44 percent.

${ }^{3}$ Low if lower general or vocational/technical; middle if middle or high general or vocational/technical; high if academic. The distribution is: 35 percent, 37 percent and 28 percent.

${ }^{4}$ Low if elementary, intermediate school, or lower vocational; middle if gymnasium or intermediate vocational; high if high vocational or university. The distribution is: 42 percent, 31 percent and 27 percent.

${ }^{5}$ Low if less than high school; middle if high school; high if beyond high school. The distribution is: 16 percent, 40 percent and 44 percent.

${ }^{6}$ Based on sums of years of schooling and formal training. The distribution is: 41 percent, 23 percent and 36 percent.
} 
Table 2b. Time Allocation of Married Women by Schooling Level (Minutes per Representative Day)

$$
\text { Australia }^{1} \text { Israel }^{2} \text { Netherlands }^{3} \text { Sweden }^{4} \begin{array}{cc}
\text { United } \\
\text { States }^{5}
\end{array} \begin{gathered}
\text { West } \\
\text { Germany }^{6}
\end{gathered}
$$

\begin{tabular}{|c|c|c|c|c|c|c|}
\hline \multicolumn{7}{|c|}{ All } \\
\hline Market work & 133 & 164 & 87 & 213 & 167 & 122 \\
\hline Home work & 276 & 229 & 257 & 205 & 254 & 312 \\
\hline Childcare & 71 & 86 & 69 & 36 & 58 & 69 \\
\hline Personal care & 617 & 624 & 650 & 612 & 643 & 647 \\
\hline Leisure & 343 & 337 & 381 & 375 & 319 & 289 \\
\hline Total nonwork & 1031 & 1047 & 1100 & 1023 & 1020 & 1006 \\
\hline \multicolumn{7}{|c|}{ Low Schooling Third } \\
\hline Market work & 104 & 82 & 49 & 187 & 122 & 114 \\
\hline Home work & 293 & 304 & 294 & 226 & 272 & 325 \\
\hline Childcare & 63 & 34 & 56 & 18 & 47 & 49 \\
\hline Personal care & 628 & 699 & 657 & 624 & 667 & 657 \\
\hline Leisure & 352 & 321 & 388 & 384 & 332 & 295 \\
\hline Total nonwork & 1043 & 1054 & 1101 & 1026 & 1046 & 1001 \\
\hline \multicolumn{7}{|c|}{ Middle Schooling Third } \\
\hline Market work & 154 & 138 & 89 & 214 & 172 & 129 \\
\hline Home work & 263 & 230 & 257 & 187 & 254 & 308 \\
\hline Childcare & 82 & 91 & 75 & 53 & 57 & 82 \\
\hline Personal care & 606 & 630 & 653 & 609 & 640 & 639 \\
\hline Leisure & 337 & 351 & 370 & 376 & 316 & 282 \\
\hline Total nonwork & 1025 & 1072 & 1098 & 1038 & 1013 & 1003 \\
\hline \multicolumn{7}{|c|}{ Top Schooling Third } \\
\hline Market work & 234 & 213 & 143 & 251 & 175 & 130 \\
\hline Home work & 219 & 201 & 206 & 194 & 246 & 290 \\
\hline Childcare & 91 & 100 & 79 & 40 & 64 & 95 \\
\hline Personal care & 587 & 595 & 635 & 595 & 634 & 637 \\
\hline Leisure & 308 & 331 & 381 & 360 & 321 & 288 \\
\hline Total nonwork & 986 & 1026 & 1095 & 995 & 1019 & 1020 \\
\hline
\end{tabular}

${ }^{1}$ The distribution is: 58 percent, 33 percent and 9 percent.

${ }^{2}$ The distribution is: 17 percent, 39 percent and 44 percent.

${ }^{3}$ The distribution is: 42 percent, 31 percent and 26 percent.

${ }^{4}$ The distribution is: 29 percent, 23 percent and 48 percent.

${ }^{5}$ The distribution is: 14 percent, 50 percent and 36 percent.

${ }^{6}$ The distribution is: 47 percent, 30 percent and 23 percent. 
Table 3. Number of Nonwork Activities of Married Persons on a Representative Day, by Schooling Level* Schooling Level

Australia

Israel

Netherlands Swede

MEN

All Respondents

$$
9.17
$$

Low Schooling Third

$$
8.77
$$

(0.09)

Middle Schooling Third 9.18

(0.09)

Top Schooling Third

10.11

(0.17)

7.72

(0.13)

7.14

(0.14)

7.40
$(0.09)$

8.94

$(0.05)$

7.04

$(0.24)$

8.44

(0.09)

8.99

(0.09)

9.44

(0.10)

6.41

(0.18)

6.61

(0.09)

7.68

0.10

8.68

(0.04)

6.68

7.32

(0.24)

8.13

(0.13)

6.68

7.57

(0.16)

8.71

(0.15)

7.95

(0.16)

9.32

(0.06)

\section{WOMEN}

All Respondents

$$
9.90
$$

(0.07)

8.15

$(0.09)$

10.03

6.91

8.69

9.97

$(0.09)$

(0.12)

Top Schooling Third

$$
\begin{aligned}
& 11.10 \\
& (0.23)
\end{aligned}
$$

(0.05)

(0.08)

(0.11)

6.83

(0.19)

9.56
$(0.07)$

6.77

(0.12)

7.89

(0.26)

9.31

8.13
$(0.13)$

10.12

(0.07)

6.96

(0.15)

8.45

(0.15)
7.05

(0.17)
9.36

(0.19)
(0.04)

(0.05)

(0.13) (0.09)

(0.09)
(0.19)

(0.17)

NOTE: Standard errors of the means are in parentheses. The educational categories are defined in the notes to Table 2. 
Table 4a. Determinants of Married Men's Demand for Diversity on a Representative Day: Human Capital Measures and the Influence of Children

\begin{tabular}{|c|c|c|c|c|c|c|}
\hline & Australia $^{1}$ & Israel $^{2}$ & Netherlands $^{3}$ & Sweden & United States & West Germany \\
\hline Education: & & & & & & \\
\hline Low Schooling Third & $\begin{array}{l}-.298 \\
(-2.659)\end{array}$ & $\begin{array}{l}-.345 \\
(-2.45)\end{array}$ & $\begin{array}{c}-.709 \\
(-4.46)\end{array}$ & $\begin{array}{l}.046 \\
(0.28)\end{array}$ & $\begin{array}{l}-.479 \\
(-2.16)\end{array}$ & $\begin{array}{l}-.506 \\
(-4.72)\end{array}$ \\
\hline Top Schooling Third & $\begin{array}{c}.923 \\
(5.81)\end{array}$ & $\begin{array}{l}.602 \\
(5.66)\end{array}$ & $\begin{array}{r}.414 \\
(2.56)\end{array}$ & $\begin{array}{l}-.231 \\
(-1.26)\end{array}$ & $\begin{array}{l}.459 \\
(2.91)\end{array}$ & $\begin{array}{l}.622 \\
(5.48)\end{array}$ \\
\hline Age & $\begin{array}{l}-.050 \\
(-1.48)\end{array}$ & $\begin{array}{l}-.080 \\
(-3.16)\end{array}$ & $\begin{array}{c}-.043 \\
(-0.89)\end{array}$ & $\begin{array}{l}-.153 \\
(-2.78)\end{array}$ & $\begin{array}{l}-.115 \\
(-2.49)\end{array}$ & $\begin{array}{l}-.238 \\
(-6.11)\end{array}$ \\
\hline $\mathrm{Age}^{2} / 100$ & $\begin{array}{l}.051 \\
(1.42)\end{array}$ & $\begin{array}{l}.133 \\
(4.13)\end{array}$ & $\begin{array}{r}.100 \\
(1.91)\end{array}$ & $\begin{array}{l}.161 \\
(2.85)\end{array}$ & $\begin{array}{l}.156 \\
(3.07)\end{array}$ & $\begin{array}{l}.266 \\
(6.69)\end{array}$ \\
\hline No. of Children & $\begin{array}{c}.425 \\
(4.05)\end{array}$ & $\begin{array}{l}.281 \\
(1.84)\end{array}$ & $\begin{array}{c}.199 \\
(1.70)\end{array}$ & $\begin{array}{l}.086 \\
(0.73)\end{array}$ & $\begin{array}{c}.014 \\
(0.13)\end{array}$ & $\begin{array}{l}.047 \\
(0.62)\end{array}$ \\
\hline \multicolumn{7}{|l|}{ Youngest child: } \\
\hline Ages 0-1 & $\begin{array}{l}-.065 \\
(-0.23)\end{array}$ & $\begin{array}{l}.709 \\
(1.52)\end{array}$ & & & & \\
\hline Ages $0-4$ or 5 & & & $\begin{array}{r}.690 \\
(3.05)\end{array}$ & $\begin{array}{l}.321 \\
(0.84)\end{array}$ & $\begin{array}{l}.234 \\
(0.73)\end{array}$ & $\begin{array}{l}.679 \\
(3.16)\end{array}$ \\
\hline Ages $2-4$ or 5 & $\begin{array}{c}.491 \\
(1.72)\end{array}$ & $\begin{array}{l}.508 \\
(1.47)\end{array}$ & & & & \\
\hline \multicolumn{7}{|l|}{ Pre-teen and/or teen: } \\
\hline Ages 5-9 & $\begin{array}{l}-.058 \\
(-0.19)\end{array}$ & & & & & \\
\hline Ages 5 or $6-17$ & & & & & $\begin{array}{c}.034 \\
(0.13)\end{array}$ & $\begin{array}{l}.433 \\
(2.51)\end{array}$ \\
\hline Ages $6-12,13$ or 14 & & $\begin{array}{c}.066 \\
(0.23)\end{array}$ & $\begin{array}{c}-.018 \\
(-0.09)\end{array}$ & $\begin{array}{r}.010 \\
(0.03)\end{array}$ & & \\
\hline Ages 10-14 & $\begin{array}{l}-.026 \\
(-0.12)\end{array}$ & & & & & \\
\hline \multicolumn{7}{|l|}{ Teen: } \\
\hline Ages 13 or $14-17$ & & $\begin{array}{l}-.379 \\
(-1.60)\end{array}$ & $\begin{array}{l}-.689 \\
(-2.69)\end{array}$ & $\begin{array}{r}-.106 \\
(-0.37)\end{array}$ & & \\
\hline $\mathrm{N}$ & 1835 & 582 & 816 & 696 & 822 & 2911 \\
\hline $\mathrm{R}^{2}$ & .089 & .135 & .151 & .029 & .054 & .100 \\
\hline
\end{tabular}

NOTE: t-statistics in parentheses. The educational categories are defined in the notes to Table 2. N denotes the number of different respondents included. Each equation includes indicators for the day of the week on which the diary is kept. Except for the United States robust standard errors that account for the duplication of observations are presented.

${ }^{1}$ The equations also include indicators of residence in the urban part of a metropolitan area, of immigrant status, and of whether English is spoken at home.

${ }^{2}$ The equations also include indicators of residence in the urban part of a metropolitan area, of ethnic origin, of health problems, of the age of the youngest child, and continuous measures of the number of children and of number of persons in the household.

${ }^{3}$ The equations also include indicators of the "long week" in this sample. 
Table 4b. Determinants of Married Women's Demand for Diversity on a Representative Day: Human Capital Measures and the Influence of Children

\begin{tabular}{|c|c|c|c|c|c|c|}
\hline & Australia $^{1}$ & Israel $^{2}$ & Netherlands ${ }^{3}$ & Sweden & United States & West Germany \\
\hline $\begin{array}{l}\text { Education: } \\
\text { Low Schooling Third }\end{array}$ & $\begin{array}{l}-.547 \\
(-4.61)\end{array}$ & $\begin{array}{l}-1.00 \\
(-2.54)\end{array}$ & $\begin{array}{c}-.550 \\
(-4.13)\end{array}$ & $\begin{array}{l}.097 \\
(0.53)\end{array}$ & $\begin{array}{l}-.507 \\
(-2.26)\end{array}$ & $\begin{array}{l}-.615 \\
(-6.03)\end{array}$ \\
\hline Top Schooling Third & $\begin{array}{r}.963 \\
(4.68)\end{array}$ & $\begin{array}{l}.471 \\
(9.58)\end{array}$ & $\begin{array}{c}.442 \\
(3.14)\end{array}$ & $\begin{array}{l}.033 \\
(0.16)\end{array}$ & $\begin{array}{l}.906 \\
(5.63)\end{array}$ & $\begin{array}{l}.657 \\
(5.15)\end{array}$ \\
\hline Age & $\begin{array}{l}.072 \\
(2.28)\end{array}$ & $\begin{array}{l}-.034 \\
(-0.45)\end{array}$ & $\begin{array}{r}.038 \\
(0.98)\end{array}$ & $\begin{array}{l}-.061 \\
(-1.16)\end{array}$ & $\begin{array}{l}-.062 \\
(-1.40)\end{array}$ & $\begin{array}{l}-.035 \\
(-1.00)\end{array}$ \\
\hline $\mathrm{Age}^{2} / 100$ & $\begin{array}{l}-.066 \\
(-1.88)\end{array}$ & $\begin{array}{l}.065 \\
(0.78)\end{array}$ & $\begin{array}{l}-.010 \\
(-0.22)\end{array}$ & $\begin{array}{l}.060 \\
(1.07)\end{array}$ & $\begin{array}{c}.086 \\
(1.74)\end{array}$ & $\begin{array}{l}.047 \\
(1.31)\end{array}$ \\
\hline No. of Children & $\begin{array}{l}.768 \\
(6.76)\end{array}$ & $\begin{array}{l}.121 \\
(3.29)\end{array}$ & $\begin{array}{r}.282 \\
(3.03)\end{array}$ & $\begin{array}{l}.070 \\
(0.59)\end{array}$ & $\begin{array}{l}.086 \\
(0.78)\end{array}$ & $\begin{array}{l}.363 \\
(4.29)\end{array}$ \\
\hline \multicolumn{7}{|l|}{$\begin{array}{l}\text { Youngest child: } \\
\text { Pre-school: }\end{array}$} \\
\hline Ages $0-1$ & $\begin{array}{l}.339 \\
(1.11)\end{array}$ & $\begin{array}{l}.883 \\
(3.15)\end{array}$ & & & & \\
\hline Ages $0-4$ or 5 & & & $\begin{array}{l}1.695 \\
(9.38)\end{array}$ & $\begin{array}{l}.919 \\
(2.46)\end{array}$ & $\begin{array}{l}1.319 \\
(3.93)\end{array}$ & $\begin{array}{l}1.269 \\
(5.39)\end{array}$ \\
\hline Ages $2-4$ or 5 & $\begin{array}{r}1.401 \\
(4.38)\end{array}$ & $\begin{array}{c}.843 \\
(3.91)\end{array}$ & & & & \\
\hline \multicolumn{7}{|l|}{ Pre-teen and/or teen: } \\
\hline Ages 5-9 & $\begin{array}{l}1.158 \\
(3.69)\end{array}$ & & & & & \\
\hline Ages 5 or $6-17$ & & & & & $\begin{array}{c}.451 \\
(1.72)\end{array}$ & $\begin{array}{l}.692 \\
(3.62)\end{array}$ \\
\hline Ages $6-12,13$ or 14 & & $\begin{array}{c}.196 \\
(1.13)\end{array}$ & $\begin{array}{r}.570 \\
(3.26)\end{array}$ & $\begin{array}{c}.543 \\
(1.69)\end{array}$ & & \\
\hline Ages 10-14 & $\begin{array}{l}.070 \\
(0.31)\end{array}$ & & & & & \\
\hline $\begin{array}{l}\text { Teen: } \\
\text { Ages } 13 \text { or } 14-17\end{array}$ & & $\begin{array}{l}-.697 \\
(-2.35)\end{array}$ & $\begin{array}{l}-.209 \\
(-0.97)\end{array}$ & $\begin{array}{r}-.039 \\
(-0.14)\end{array}$ & & \\
\hline $\mathrm{N}$ & 2031 & 582 & 816 & 756 & 1286 & 2968 \\
\hline $\mathrm{R}^{2}$ & .231 & .129 & .145 & .060 & .069 & .129 \\
\hline
\end{tabular}

NOTE: $\mathrm{t}$-statistics in parentheses. The educational categories are defined in the notes to Table $2 . \mathrm{N}$ denotes the number of different respondents included. Each equation includes indicators for the day of the week on which the diary is kept. Except for the United States robust standard errors that account for the duplication of observations are presented.

${ }^{1}$ The equations also include indicators of residence in the urban part of a metropolitan area, of immigrant status, and of whether English is spoken at home.

${ }^{2}$ The equations also include indicators of residence in the urban part of a metropolitan area, of ethnic origin, of health problems, of the age of the youngest child, and continuous measures of the number of children and of number of persons in the household.

${ }^{3}$ The equations also include indicators of the "long week" in this sample. 
Table 5. Determinants of Married People's Demand for Diversity: Adding Earnings and/or Income

\begin{tabular}{|c|c|c|c|c|}
\hline Education: & Age & $\operatorname{Age}^{2} / 100$ & Wage & Income $/ \mathbf{1 0 0}$ \\
\hline High & & & & \\
\hline
\end{tabular}

\begin{tabular}{|c|c|c|c|c|c|c|c|}
\hline $\begin{array}{l}\text { Australia } \\
\qquad(\text { Men } N=1672)\end{array}$ & $\begin{array}{c}-.324 \\
(-2.78)\end{array}$ & $\begin{array}{l}.900 \\
(5.24)\end{array}$ & $\begin{array}{l}-.028 \\
(-0.78)\end{array}$ & $\begin{array}{l}.028 \\
(0.74)\end{array}$ & & $\begin{array}{l}.0063 \\
(1.08)\end{array}$ & .099 \\
\hline$($ Women $\mathrm{N}=1854$ ) & $\begin{array}{c}-.547 \\
(-4.38)\end{array}$ & $\begin{array}{c}.866 \\
(4.07)\end{array}$ & $\begin{array}{l}.077 \\
(2.25)\end{array}$ & $\begin{array}{l}-.068 \\
(-1.80)\end{array}$ & & $\begin{array}{l}.0086 \\
(1.52)\end{array}$ & .231 \\
\hline $\begin{array}{l}\text { Israel } \\
(\text { Men } N=500)\end{array}$ & $\begin{array}{l}-.156 \\
\quad(-1.33)\end{array}$ & $\begin{array}{l}.600 \\
(4.87)\end{array}$ & $\begin{array}{c}-.112 \\
(-3.70)\end{array}$ & $\begin{array}{c}.165 \\
(5.22)\end{array}$ & & $\begin{array}{l}.0102 \\
(3.98)\end{array}$ & .154 \\
\hline (Women $\mathrm{N}=130$ ) & $\begin{array}{l}-.921 \\
(-2.66)\end{array}$ & $\begin{array}{l}.371 \\
(4.12)\end{array}$ & $\begin{array}{l}-.107 \\
(-1.03)\end{array}$ & $\begin{array}{l}.154 \\
(1.26)\end{array}$ & & $\begin{array}{l}.0058 \\
(5.19)\end{array}$ & .150 \\
\hline $\begin{array}{l}\text { Sweden } \\
\quad(\text { Men } N=606)\end{array}$ & $\begin{array}{l}-.016 \\
(-0.10)\end{array}$ & $\begin{array}{l}-.180 \\
(-0.99)\end{array}$ & $\begin{array}{l}-.111 \\
(-1.96)\end{array}$ & $\begin{array}{l}.116 \\
(1.98)\end{array}$ & $\begin{array}{l}-.0031 \\
(-2.15)\end{array}$ & & .033 \\
\hline$($ Women $\mathrm{N}=656)$ & $\begin{array}{l}.089 \\
(0.52)\end{array}$ & $\begin{array}{c}.099 \\
(0.56)\end{array}$ & $\begin{array}{l}-.052 \\
(-1.05)\end{array}$ & $\begin{array}{r}.052 \\
(0.97)\end{array}$ & $\begin{array}{l}-.0028 \\
(-1.73)\end{array}$ & & .061 \\
\hline $\begin{array}{l}\text { West Germany } \\
\quad(\text { Men } N=2827)\end{array}$ & $\begin{array}{l}-.484 \\
(-4.47)\end{array}$ & $\begin{array}{c}.614 \\
(5.35)\end{array}$ & $\begin{array}{l}-.250 \\
(-6.19)\end{array}$ & $\begin{array}{l}.279 \\
(6.76)\end{array}$ & & $\begin{array}{l}.0021 \\
(0.52)\end{array}$ & .106 \\
\hline$($ Women $\mathrm{N}=2891)$ & $\begin{array}{l}-.516 \\
(-5.03)\end{array}$ & $\begin{array}{c}.497 \\
(3.77)\end{array}$ & $\begin{array}{l}-.082 \\
(-2.26)\end{array}$ & $\begin{array}{c}.0966 \\
(2.58)\end{array}$ & & $\begin{array}{l}.0167 \\
(6.99)\end{array}$ & .139 \\
\hline
\end{tabular}

NOTE: $t$-statistics in parentheses. The equations are specified identically to those presented in Tables 4, except wage or income measures are included. For Sweden the wage measure is earnings per hour. The income measures are weekly household income, own earnings excluded, for Australia, monthly family income, own earnings excluded, for Israel, and spouse's income for West Germany. 
Table 6. Fraction of Activities Dominated by the More Educated Group

$$
\text { Australia Israel Netherlands United States West Germany }
$$

Men

High vs. Low

$.604 \quad .672$

.551

.619

.681

High vs. Middle

$.667 \quad .750$

.659

.677

.766

Education

Middle vs. Low

$.633 \quad .609$

.567

.656

.637

Education

Women

High vs. Low

$.465 \quad .781$

.612

.797

.714

Education

High vs. Middle

$.518 \quad .797$

.677

.823

.718

Education

$.653 \quad .594$

.597

.645

.692 
Table 7. Number of Nonwork Activities by Duration on a Representative Day

\begin{tabular}{|c|c|c|c|c|c|c|c|}
\hline Duration (in minutes) & $1-59$ & $60-119$ & $120-239$ & 240-359 & $360-479$ & $480+$ & $\begin{array}{c}\text { Total No. } \\
\text { of Activities }\end{array}$ \\
\hline Australia: & 4.82 & 1.84 & 0.98 & 0.33 & 0.54 & 0.65 & 9.17 \\
\hline Low Schooling Third & 4.42 & 1.76 & 1.02 & 0.37 & 0.50 & 0.71 & 8.77 \\
\hline Middle Schooling Third & 4.86 & 1.84 & 0.98 & 0.31 & 0.55 & 0.64 & 9.18 \\
\hline Top Schooling Third & 5.72 & 2.03 & 0.89 & 0.31 & 0.62 & 0.54 & 10.11 \\
\hline Women & 5.60 & 2.00 & 0.97 & 0.26 & 0.45 & 0.62 & 9.90 \\
\hline Low Schooling Third & 5.17 & 1.98 & 0.99 & 0.27 & 0.42 & 0.65 & 9.48 \\
\hline Middle Schooling Third & 6.02 & 2.01 & 0.96 & 0.26 & 0.47 & 0.60 & 10.32 \\
\hline Top Schooling Third & 6.79 & 2.05 & 0.90 & 0.25 & 0.61 & 0.50 & 11.10 \\
\hline Israel: & 3.07 & 1.90 & 1.06 & 0.42 & 0.51 & 0.43 & 7.40 \\
\hline Low Schooling Third & 2.37 & 1.91 & 1.20 & 0.53 & 0.45 & 0.59 & 7.04 \\
\hline Middle Schooling Third & 2.91 & 1.83 & 1.05 & 0.42 & 0.48 & 0.46 & 7.14 \\
\hline Top Schooling Third & 3.41 & 1.96 & 1.04 & 0.40 & 0.55 & 0.37 & 7.72 \\
\hline Women & 3.37 & 2.19 & 1.24 & 0.37 & 0.44 & 0.53 & 8.15 \\
\hline Low Schooling Third & 2.40 & 1.76 & 1.28 & 0.34 & 0.37 & 0.68 & 6.83 \\
\hline Middle Schooling Third & 3.25 & 2.26 & 1.23 & 0.39 & 0.44 & 0.59 & 8.13 \\
\hline Top Schooling Third & 3.82 & 2.28 & 1.23 & 0.36 & 0.46 & 0.46 & 8.61 \\
\hline Netherlands: Men & 4.26 & 2.25 & 1.12 & 0.28 & 0.52 & 0.51 & 8.94 \\
\hline Low Schooling Third & 3.72 & 2.15 & 1.22 & 0.32 & 0.49 & 0.53 & 8.44 \\
\hline Middle Schooling Third & 4.36 & 2.26 & 1.10 & 0.27 & 0.52 & 0.48 & 8.99 \\
\hline Top Schooling Third & 4.81 & 2.34 & 1.00 & 0.23 & 0.54 & 0.50 & 9.44 \\
\hline Women & 4.98 & 2.66 & 1.15 & 0.20 & 0.42 & 0.63 & 10.03 \\
\hline Low Schooling Third & 4.51 & 2.60 & 1.19 & 0.22 & 0.38 & 0.67 & 9.56 \\
\hline Middle Schooling Third & 5.11 & 2.62 & 1.15 & 0.19 & 0.43 & 0.62 & 10.12 \\
\hline Top Schooling Third & 5.41 & 2.79 & 1.09 & 0.17 & 0.46 & 0.58 & 10.50 \\
\hline Sweden: & 2.73 & 1.49 & 1.00 & 0.34 & 0.57 & 0.48 & 6.61 \\
\hline Low Schooling Third & 2.69 & 1.48 & 1.07 & 0.37 & 0.55 & 0.53 & 6.68 \\
\hline Middle Schooling Third & 2.79 & 1.48 & 1.04 & 0.31 & 0.60 & 0.46 & 6.68 \\
\hline Top Schooling Third & 2.73 & 1.50 & 0.87 & 0.33 & 0.57 & 0.42 & 6.41 \\
\hline Women & 2.90 & 1.69 & 1.00 & 0.27 & 0.48 & 0.57 & 6.91 \\
\hline Low Schooling Third & 2.74 & 1.63 & 1.04 & 0.31 & 0.46 & 0.59 & 6.77 \\
\hline Middle Schooling Third & 2.92 & 1.69 & 1.03 & 0.28 & 0.47 & 0.56 & 6.96 \\
\hline Top Schooling Third & 3.10 & 1.79 & 0.91 & 0.21 & 0.50 & 0.53 & 7.05 \\
\hline United States: Men & 3.67 & 1.72 & 0.94 & 0.34 & 0.53 & 0.47 & 7.68 \\
\hline Low Schooling Third & 3.00 & 1.77 & 1.12 & 0.43 & 0.47 & 0.52 & 7.32 \\
\hline Middle Schooling Third & 3.57 & 1.69 & 0.92 & 0.36 & 0.55 & 0.46 & 7.57 \\
\hline Top Schooling Third & 4.03 & 1.74 & 0.89 & 0.30 & 0.54 & 0.46 & 7.95 \\
\hline Women & 4.21 & 2.18 & 0.97 & 0.33 & 0.46 & 0.53 & 8.69 \\
\hline Low Schooling Third & 3.41 & 2.03 & 0.94 & 0.44 & 0.47 & 0.59 & 7.89 \\
\hline Middle Schooling Third & 4.02 & 2.12 & 0.98 & 0.33 & 0.48 & 0.53 & 8.45 \\
\hline Top Schooling Third & 4.80 & 2.33 & 0.97 & 0.28 & 0.44 & 0.52 & 9.36 \\
\hline
\end{tabular}




\begin{tabular}{|c|c|c|c|c|c|c|c|}
\hline West Germany: Men & 4.86 & 1.80 & 0.82 & 0.23 & 0.52 & 0.45 & 8.69 \\
\hline Low Schooling Third & 4.35 & 1.70 & 0.87 & 0.25 & 0.50 & 0.47 & 8.14 \\
\hline Middle Schooling Third & 4.86 & 1.82 & 0.81 & 0.23 & 0.52 & 0.47 & 8.71 \\
\hline Top Schooling Third & 5.46 & 1.91 & 0.78 & 0.21 & 0.56 & 0.41 & 9.32 \\
\hline Women & 5.79 & 2.11 & 0.89 & 0.18 & 0.47 & 0.53 & 9.97 \\
\hline Low Schooling Third & 5.18 & 2.01 & 0.92 & 0.18 & 0.45 & 0.56 & 9.31 \\
\hline Middle Schooling Third & 6.06 & 2.14 & 0.88 & 0.18 & 0.48 & 0.50 & 10.23 \\
\hline Top Schooling Third & 6.73 & 2.28 & 0.86 & 0.16 & 0.51 & 0.48 & 11.02 \\
\hline
\end{tabular}

NOTE: Except for rounding the row-sum equals the entry in the last column, which is copied from Table 3. 
Table 8. Number of Routine (R) and Nonroutine (NR) Nonwork Activities of Married People, by Schooling Level

\begin{tabular}{|c|c|c|c|c|c|c|}
\hline & \multicolumn{2}{|c|}{ Australia } & \multicolumn{2}{|c|}{ Israel } & Sweden & West Germany \\
\hline & $\mathbf{R}$ & NR & $\mathbf{R}$ & NR & R NR & NR \\
\hline & \multicolumn{6}{|c|}{ Men } \\
\hline All Respondents & $\begin{array}{l}6.34 \\
(0.05)\end{array}$ & $\begin{array}{l}5.67 \\
(0.08)\end{array}$ & $\begin{array}{l}5.05 \\
(0.11)\end{array}$ & $\begin{array}{l}4.61 \\
(0.18)\end{array}$ & $\begin{array}{cc}3.93 & 5.53 \\
(0.08) & (0.10)\end{array}$ & $\begin{array}{ll}5.71 & 5.93 \\
(0.02) & (0.04)\end{array}$ \\
\hline Low Schooling Third & $\begin{array}{c}6.18 \\
(0.07)\end{array}$ & $\begin{array}{c}5.17 \\
(0.12)\end{array}$ & $\begin{array}{c}5.23 \\
(0.53)\end{array}$ & $\begin{array}{c}4.08 \\
(0.62)\end{array}$ & $\begin{array}{cc}4.04 & 5.34 \\
(0.12) & (0.17)\end{array}$ & $\begin{array}{ll}5.44 & 5.39 \\
(0.03) & (0.06)\end{array}$ \\
\hline Middle Schooling Third & $\begin{array}{l}6.34 \\
(0.07)\end{array}$ & $\begin{array}{l}5.73 \\
(0.12)\end{array}$ & $\begin{array}{l}5.03 \\
(0.18)\end{array}$ & $\begin{array}{l}4.36 \\
(0.27)\end{array}$ & $\begin{array}{cc}3.95 & 5.74 \\
(0.13) & (0.16)\end{array}$ & $\begin{array}{cc}5.72 & 5.97 \\
(0.05) & (0.08)\end{array}$ \\
\hline Top Schooling Third & $\begin{array}{c}6.74 \\
(0.12)\end{array}$ & $\begin{array}{c}6.71 \\
(0.20)\end{array}$ & $\begin{array}{l}5.03 \\
(0.15)\end{array}$ & $\begin{array}{l}4.89 \\
(0.27)\end{array}$ & $\begin{array}{cc}3.74 & 5.59 \\
(0.15) & (0.19)\end{array}$ & $\begin{array}{cc}6.04 & 6.55 \\
(0.04) & (0.07)\end{array}$ \\
\hline
\end{tabular}

\section{Women}

$\begin{array}{lcccccccc}\text { All Respondents } & 6.63 & 6.59 & 5.72 & 5.19 & 4.16 & 5.49 & 6.51 & 6.91 \\ & (0.05)(0.08) & (0.13)(0.19) & (0.07)(0.09) & (0.03)(0.06) \\ \text { Low Schooling Third } & 6.42 & 6.12 & 4.74 & 4.04 & 4.27 & 5.05 & 6.14 & 6.33 \\ & (0.06)(0.10) & (0.29)(0.57) & (0.10)(0.14) & (0.03)(0.04) \\ \text { Middle Schooling Third } & 6.74 & 7.26 & 5.89 & 5.15 & 4.05 & 5.78 & 6.63 & 7.21 \\ & (0.09)(0.15) & (0.20)(0.29) & (0.13)(0.16) & (0.04)(0.08) \\ \text { Top Schooling Third } & 7.52 & 7.14 & 5.83 & 5.49 & 4.11 & 5.85 & 7.16 & 7.73 \\ & (0.16)(0.16) & (0.18)(0.27) & (0.15)(0.18) & (0.06)(0.09)\end{array}$

NOTE: Standard errors of the means are in parentheses. The educational categories are defined in the notes to Table 2 . 
Table 9a. Determinants of Married Men's Demand for Diversity in Routine (R) and Nonroutine (NR) Activities

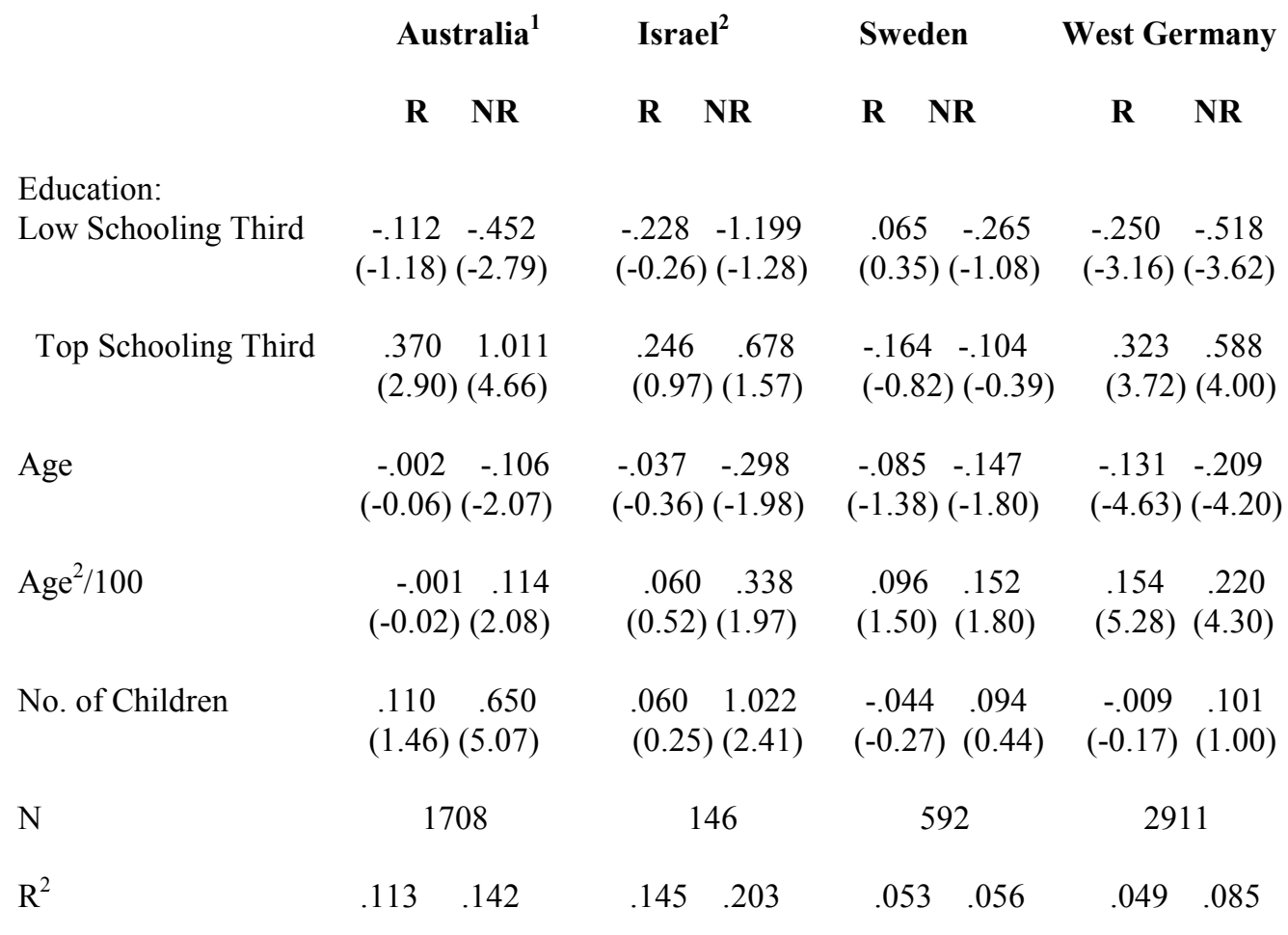

NOTE: t-statistics in parentheses. The educational categories are defined in the notes to Table 2. Each equation includes indicators for the days of the week on which the diary is kept and for the age of the youngest child.

${ }^{1}$ The equations also include indicators of residence in the urban part of a metropolitan area, of immigrant status, and of whether English is spoken at home.

${ }^{2}$ The equations also include indicators of residence in the urban part of a metropolitan area, of ethnic origin, of health problems, of the age of the youngest child, and continuous measures of the number of children and of number of persons in the household. 
Table 9b. Determinants of Married Women's Demand for Diversity in Routine (R) and Nonroutine (NR) Activities

\begin{tabular}{|c|c|c|c|c|}
\hline & Australia $^{1}$ & Israel $^{2}$ & Sweden & West Germany \\
\hline & R NR & R NR & NR & NR \\
\hline $\begin{array}{l}\text { Education: } \\
\text { Low Schooling Third }\end{array}$ & $\begin{array}{cc}-.071 & -.901 \\
(-0.72) & (-5.55)\end{array}$ & $\begin{array}{ll}-1.017 & -1.403 \\
(-2.07) & (-1.29)\end{array}$ & $\begin{array}{ll}.473 & -.495 \\
(2.52) & (-2.10)\end{array}$ & $\begin{array}{ll}-.260 & -.711 \\
(-3.41) & (-5.20)\end{array}$ \\
\hline Top Schooling Third & $\begin{array}{cc}.872 & .132 \\
(5.21) & (0.49)\end{array}$ & $\begin{array}{lc}-.002 & .243 \\
(-001) & (0.49)\end{array}$ & $\begin{array}{ll}.197 & .035 \\
(1.91) & (0.15)\end{array}$ & $\begin{array}{lc}.423 & .467 \\
(4.38) & (2.82)\end{array}$ \\
\hline Age & $\begin{array}{cc}.045 & .038 \\
(-1.46) & (0.81)\end{array}$ & $\begin{array}{ll}-.188 & -.249 \\
(-1.54) & (-1.31)\end{array}$ & $\begin{array}{cc}-.115 & .001 \\
(-2.24) & (0.02)\end{array}$ & $\begin{array}{cl}-.033 & -.004 \\
(-1.28) & (-0.10)\end{array}$ \\
\hline $\mathrm{Age}^{2} / 100$ & $\begin{array}{rr}-.046 & -.020 \\
(-1.46) & (-0.40)\end{array}$ & $\begin{array}{lc}.247 & .339 \\
(1.91) & (1.60)\end{array}$ & $\begin{array}{ll}.113 & -.004 \\
(2.07) & (-0.05)\end{array}$ & $\begin{array}{cc}.043 & .007 \\
(1.62) & (0.16)\end{array}$ \\
\hline No. of Children & $\begin{array}{lc}.335 & .874 \\
(4.19) & (6.74)\end{array}$ & $\begin{array}{cc}-.045 & .719 \\
(-0.20) & (1.27)\end{array}$ & $\begin{array}{cc}-.047 & .178 \\
(-0.42) & (1.28)\end{array}$ & $\begin{array}{cc}.184 & .354 \\
(2.89) & (3.31)\end{array}$ \\
\hline $\mathrm{N}$ & 1870 & 149 & 634 & 2968 \\
\hline $\mathrm{R}^{2}$ & $\begin{array}{ll}.113 & .198\end{array}$ & $.145 \quad .220$ & $.053 \quad .061$ & $.142 \quad .064$ \\
\hline
\end{tabular}

Note: t-statistics in parentheses. The educational categories are defined in the notes to Table 2. Each equation includes indicators for the days of the week on which the diary is kept and for the age of the youngest child.

${ }^{1}$ The equations also include indicators of residence in the urban part of a metropolitan area, of immigrant status, and of whether English is spoken at home.

${ }^{2}$ The equations also include indicators of residence in the urban part of a metropolitan area, of ethnic origin, of health problems, of the age of the youngest child, and continuous measures of the number of children and of number of persons in the household. 
Table 10. Number of Nonwork Activities of Married People by Schooling Level, Weekdays (Day) and Weekends (End)

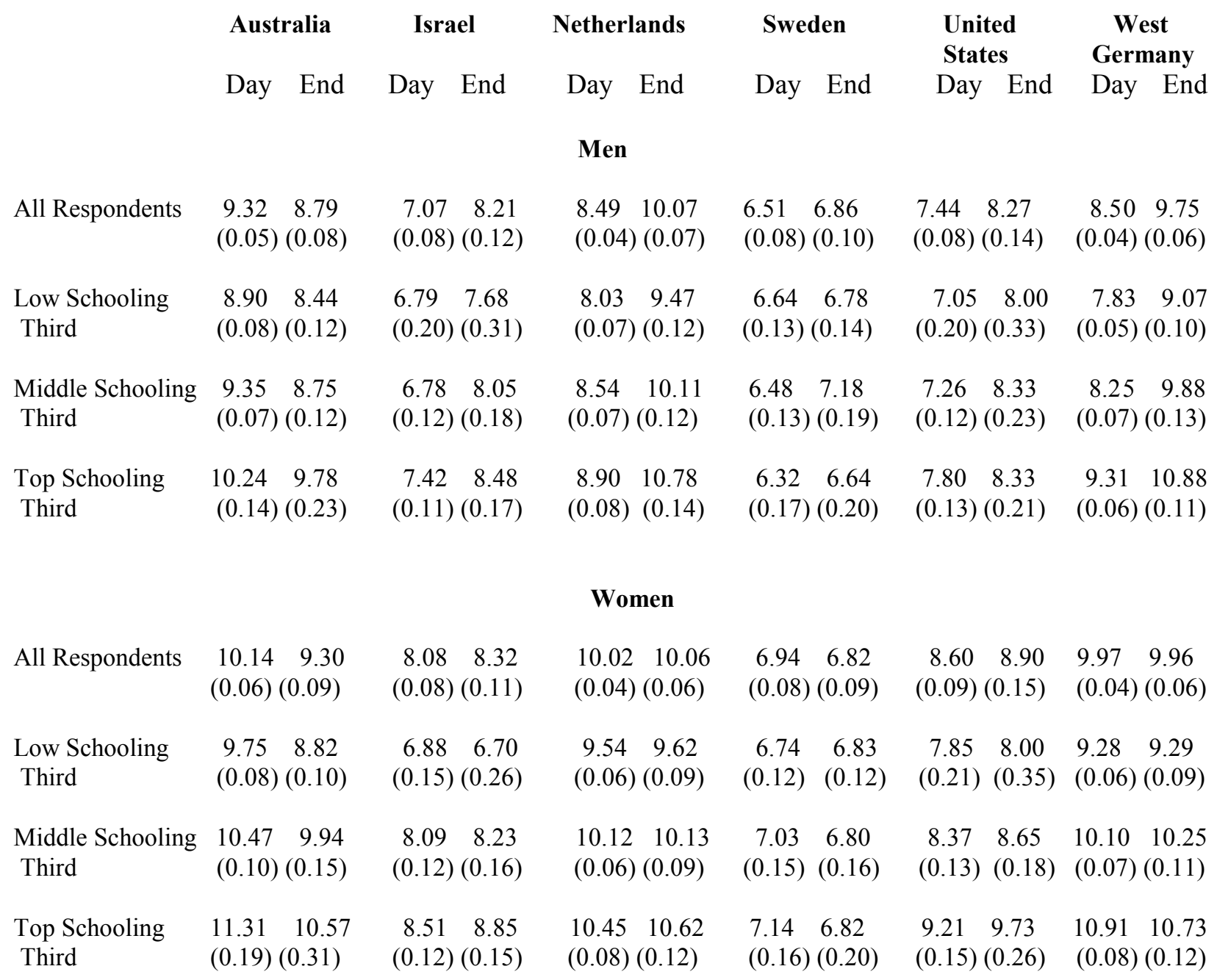

NOTE: The first number for each country is for the average weekday, the second for the average weekend day. Standard errors of the means are in parentheses. The educational categories are defined in the notes to Table 2. 
Appendix Table 1. Determinants of the Time Allocation of Married People on a Representative Day

\section{Australia $^{1}$ Men}

Total Nonwork

Leisure

Personal Care

\section{Women}

Total Nonwork

Leisure

Personal Care

Israel $^{2}$ Men

Total Nonwork

Leisure

Personal Care

\section{Women}

Total Nonwork

Leisure

Personal Care

Netherlands ${ }^{3}$ Men

Total Nonwork

Leisure

Personal Care

\begin{tabular}{cccccc}
\multicolumn{2}{c}{ Education: } & Age $\operatorname{Age}^{2} / 100$ & Wage Income $/ 100$ & $\mathbf{R}^{2}$
\end{tabular}

$\begin{array}{llllll}28.54 & 17.54 & -20.65 & 27.38 & -2.723 & .272 \\ (2.73) & (1.26) & (-6.48) & (8.02) & (-5.00) & \\ & & & & & \\ 9.50 & 19.81 & -17.29 & 21.71 & -1.492 & .203 \\ (1.01) & (1.60) & (-5.93) & (6.90) & (-3.26) & \\ & & & & & \\ 18.16 & -12.29 & -3.26 & 5.37 & -1.164 & .122 \\ (3.17) & (-1.81) & (-1.93) & (2.94) & (-4.60) & \end{array}$

$\begin{array}{llll}15.22 & -31.09 & -12.49 & 17.03\end{array}$

$\begin{array}{llll}(1.87) & (-2.16) & (-5.19) & (6.56)\end{array}$

$-2.060 \quad .204$

$(-5.26)$

$\begin{array}{llll}0.55 & -25.31 & -10.00 & 13.81 \\ (0.07) & (-2.02) & (-4.39) & (5.47)\end{array}$

$-.699 \quad .143$
$-1.95)$

$(-1.95)$

$14.89 \quad-10.78 \quad-2.30 \quad 2.86$

$-1.237 \quad .107$

$\begin{array}{llll}(3.01) \quad(-1.29) & (-1.57) \quad(1.75)\end{array}$

$(-5.46)$

$\begin{array}{lccccc}53.18 & 10.44 & -32.31 & 37.81 & .591 & .440 \\ (2.75) & (0.79) & (-7.89) & (10.39) & (0.90) & \\ & & & & & \\ -22.67 & 10.83 & -19.85 & 23.30 & .655 & .279 \\ (-4.04) & (1.02) & (-13.78) & (42.49) & (1.50) & \\ & & & & & \\ 66.09 & -6.22 & -12.90 & 14.87 & -.260 & .283 \\ (3.73) & (-0.51) & (-3.24) & (3.17) & (-0.73) & \end{array}$

$$
\begin{array}{lccc}
66.09 & -6.22 & -12.90 & 14.87 \\
(3.73) & (-0.51) & (-3.24) & (3.17)
\end{array}
$$

$(-0.73)$

$-.011 \quad .344$

$(-0.13)$

$$
\begin{array}{llll}
-20.81 & -36.53 & -19.78 & 25.04 \\
(-3.81) & (-2.43) & (-14.50) & (16.88)
\end{array}
$$

$.270 \quad .275$

$\begin{array}{llll}-69.68 & -30.51 & -10.01 & 13.90\end{array}$

(4.49)

$\begin{array}{llll}(-4.36) \quad(-9.13) & (-5.36) \quad(7.88)\end{array}$

$-.228 \quad .226$

$\begin{array}{llll}46.41 & -22.43 & -11.30 & 13.14\end{array}$

$\begin{array}{llll}(2.46) & (-1.46) & (-10.27) & (6.44)\end{array}$

.457

$\begin{array}{llll}(0.64) \quad(0.54) \quad(-3.80) & (5.87)\end{array}$

.342

$\begin{array}{llll}-7.48 & 5.02 & -8.48 & 13.46\end{array}$

$\begin{array}{llll}(-0.75) & (0.53) & (-2.88) & (4.23)\end{array}$

.207 


\section{$\begin{array}{cccccc}\text { Education: } & \text { Age } & \mathrm{Age}^{2} / 100 & \text { Wage Income/100 } & \mathrm{R}^{2}\end{array}$}

\section{Women}

Total Nonwork

Leisure

$\begin{array}{ccll}-5.83 & -.79 & -4.43 & 7.70 \\ (-0.78) & (-0.09) & (-1.92) & (3.04) \\ 1.87 & 12.21 & -0.92 & 3.21 \\ (0.27) & (1.57) & (-0.45) & (1.38)\end{array}$

.264

$\begin{array}{lllc}-2.08 & -17.95 & -4.43 & 5.93 \\ (-0.33) & (-3.14) & (-2.42) & (2.99)\end{array}$

.100

Personal Care

Sweden $^{4}$ Men

Total Nonwork

$\begin{array}{lllll}6.79 & -37.64 & -34.54 & 40.10 & -.446 \\ (0.36) & (-2.04) & (-5.17) & (5.98) & (-2.68)\end{array}$

.312

Leisure

$\begin{array}{llllll}-10.59 & -23.67 & -21.61 & 26.95 & -.263 & .162\end{array}$

Personal Care

$\begin{array}{llll}(-0.51) \quad(-1.08) \quad(-3.24) \quad(3.89) \quad(-1.58) & -(1.5)\end{array}$

.180

$\begin{array}{llllll}18.02 & -15.94 & -9.84 & 11.01 & -.140 & .067\end{array}$

Women

Total Nonwork

$(1.44) \quad(-1.12) \quad(-2.15) \quad(2.35) \quad(-1.20)$

Leisure

$\begin{array}{lllll}(-1.84) & (-1.56) & (-6.60) & (7.21) & (-3.59)\end{array}$

$\begin{array}{llllll}-35.24 & -10.10 & -24.93 & 30.65 & -.144 & .108\end{array}$

$\begin{array}{llll}(-1.69) \quad(-0.48) & (-3.99) \quad(4.53) \quad(-0.76)\end{array}$

.108

Personal Care

$\begin{array}{lllll}17.20 & -7.62 & -2.71 & 2.28 & -.275 \\ (1.25) & (-0.52) & (-0.59) & (0.46) & (-2.14)\end{array}$

.037

United States ${ }^{5}$ Men

Total Nonwork

$\begin{array}{llll}-15.44 & -12.91 & -20.69 & 27.72\end{array}$

.254

$(-0.77) \quad(-0.90) \quad(-4.93) \quad(6.00)$

.173

$\begin{array}{llll}(-2.52) & (-1.38) \quad(-3.55) \quad(4.42)\end{array}$

Personal Care

$\begin{array}{llll}20.88 & 3.75 & -8.73 & 11.17\end{array}$

.112

$(1.73) \quad(0.44) \quad(-3.47) \quad(4.04)$

\section{Women}

Total Nonwork

$\begin{array}{llll}30.64 & 12.83 & -17.10 & 20.75 \\ (1.80) & (1.05) & (-5.12) & (5.52)\end{array}$

.109

Leisure

1.80

$11.52-8.35$

11.13

.083

Personal Care

$(0.12)$

(1.11) (-2.94)

(3.48)

$\begin{array}{llll}19.71 & -3.26 & -4.74 & 6.25\end{array}$

(1.86)

$(-0.43) \quad(-2.27)$

(2.67) 


\section{Education: Age $\mathbf{A g e}^{2} / 100$ Wage Income/100 $\mathbf{R}^{2}$ \\ Low High}

\begin{tabular}{|c|c|c|c|c|c|c|}
\hline West Germany $^{6}$ Men & & & & & & \\
\hline Total Nonwork & $\begin{array}{l}-1.00 \\
(0.12)\end{array}$ & $\begin{array}{l}2.46 \\
(0.31)\end{array}$ & $\begin{array}{l}-30.04 \\
(-10.25)\end{array}$ & $\begin{array}{l}36.09 \\
(11.98)\end{array}$ & $\begin{array}{l}-0.369 \\
(-1.09)\end{array}$ & .403 \\
\hline Leisure & $\begin{array}{l}-1.40 \\
(-0.22)\end{array}$ & $\begin{array}{l}4.85 \\
(0.78)\end{array}$ & $\begin{array}{l}-17.13 \\
(-7.05)\end{array}$ & $\begin{array}{l}20.05 \\
(8.00)\end{array}$ & $\begin{array}{l}-0.100 \\
(-0.36)\end{array}$ & .259 \\
\hline Personal Care & $\begin{array}{l}6.53 \\
(1.36)\end{array}$ & $\begin{array}{l}-2.50 \\
(-0.55)\end{array}$ & $\begin{array}{l}-10.95 \\
(-6.62)\end{array}$ & $\begin{array}{l}14.28 \\
(8.31)\end{array}$ & $\begin{array}{l}-0.299 \\
(-1.64)\end{array}$ & .234 \\
\hline $\begin{array}{c}\text { Women } \\
\text { Total Nonwork }\end{array}$ & $\begin{array}{c}6.67 \\
(1.07)\end{array}$ & $\begin{array}{c}8.26 \\
(1.13)\end{array}$ & $\begin{array}{l}-22.8 \\
(-10.06)\end{array}$ & $\begin{array}{r}0.265 \\
(11.33)\end{array}$ & $\begin{array}{l}1.213 \\
(6.39)\end{array}$ & .245 \\
\hline Leisure & $\begin{array}{l}3.66 \\
(0.70)\end{array}$ & $\begin{array}{l}7.17 \\
(1.12)\end{array}$ & $\begin{array}{l}-9.70 \\
(-4.99)\end{array}$ & $\begin{array}{l}11.52 \\
(5.56)\end{array}$ & $\begin{array}{l}.919 \\
(5.74)\end{array}$ & .144 \\
\hline Personal Care & $\begin{array}{l}7.51 \\
(1.97)\end{array}$ & $\begin{array}{c}1.42 \\
(0.31)\end{array}$ & $\begin{array}{c}-7.80 \\
(-5.31)\end{array}$ & $\begin{array}{r}10.03 \\
(6.29)\end{array}$ & $\begin{array}{l}.144 \\
(1.30)\end{array}$ & .155 \\
\hline
\end{tabular}

NOTE: $\mathrm{t}$-statistics in parentheses. $\mathrm{N}$ denotes the number of different respondents included. Each equation includes indicators for the day of the week on which the diary is kept. Except for the United States robust standard errors that account for the duplication of observations are presented.

\footnotetext{
${ }^{1}$ The equations also include indicators of residence in the urban part of a metropolitan area, of immigrant status, of whether English is spoken at home and of the age of the youngest child, and a continuous measure of the number of children. Income is weekly household income, own earnings excluded.

${ }^{2}$ The equations also include indicators of residence in the urban part of a metropolitan area, of ethnic origin, of health problems, of the age of the youngest child, as well as continuous measures of the number of children and of number of persons in the household. Income is monthly family income, own earnings excluded.

${ }^{3}$ The equations also include indicators of the "long week" in this sample and of the age of the youngest child, and a continuous measure of the number of children.

${ }^{4}$ The equations also include indicators of the age of the youngest child, and a continuous measure of the number of children. The wage measure is gross hourly earnings.

${ }^{5}$ The equations also include indicators of the age of the youngest child, and a continuous measure of the number of children.

${ }^{6}$ The equations also include indicators of the age of the youngest child, and a continuous measure of the number of children. Income is spouse's income.
} 